\title{
AOW Monitor 2021: Effect van verhoging van de AOW- leeftijd op werk, inkomen en gezondheid
}

Citation for published version (APA):

Montizaan, R., Goedhart, R., \& Bijlsma, I. (2021). AOW Monitor 2021: Effect van verhoging van de AOWleeftijd op werk, inkomen en gezondheid. ROA. ROA Reports No. 002

https://doi.org/10.26481/umarep.2021002

Document status and date:

Published: 07/06/2021

DOI:

10.26481/umarep.2021002

Document Version:

Publisher's PDF, also known as Version of record

\section{Please check the document version of this publication:}

- A submitted manuscript is the version of the article upon submission and before peer-review. There can be important differences between the submitted version and the official published version of record.

People interested in the research are advised to contact the author for the final version of the publication, or visit the DOI to the publisher's website.

- The final author version and the galley proof are versions of the publication after peer review.

- The final published version features the final layout of the paper including the volume, issue and page numbers.

Link to publication

\footnotetext{
General rights rights.

- You may freely distribute the URL identifying the publication in the public portal. please follow below link for the End User Agreement:

www.umlib.nl/taverne-license

Take down policy

If you believe that this document breaches copyright please contact us at:

repository@maastrichtuniversity.nl

providing details and we will investigate your claim.
}

Copyright and moral rights for the publications made accessible in the public portal are retained by the authors and/or other copyright owners and it is a condition of accessing publications that users recognise and abide by the legal requirements associated with these

- Users may download and print one copy of any publication from the public portal for the purpose of private study or research.

- You may not further distribute the material or use it for any profit-making activity or commercial gain

If the publication is distributed under the terms of Article $25 \mathrm{fa}$ of the Dutch Copyright Act, indicated by the "Taverne" license above, 


\section{AOW Monitor 2021: Effect van verhoging van de AOW-leeftijd op werk, inkomen en gezondheid}

Raymond Montizaan

Rogier Goedhart

Ineke Bijlsma

\section{ROA Rapport}

ROA-R-2021/2

Researchcentrum voor Onderwijs en Arbeidsmarkt | ROA Research Centre for Education and the Labour Market / ROA 


\title{
Colofon
}

(c) Researchcentrum voor Onderwijs en Arbeidsmarkt (ROA). Niets uit deze uitgave mag op enige manier worden verveelvoudigd zonder voorafgaande schriftelijke toestemming van de directeur van het ROA.

\author{
Researchcentrum voor Onderwijs en Arbeidsmarkt \\ Postbus 616 \\ 6200 MD Maastricht \\ $\mathrm{T}+31433883647$ \\ secretary-roa-sbe@maastrichtuniversity.nl \\ www.roa.nl \\ School of Business and Economics \\ Maastricht University

\section{Vormgeving} \\ ROA secretariaat, Maastricht
}

ISBN: 978-90-5321-598-2

ISSN: 2666-8858

mei 2021 


\section{Inhoud}

Samenvatting v v

1 Inleiding: Aanleiding, doel en onderzoeksopzet 1

1.2 Doel 2

1.3 Onderzoeksopzet 2

$\begin{array}{ll}1.4 & \text { Opzet rapportage } \\ \end{array}$

2 Wensen en mogelijkheden $\quad 5$

2.1 Wensen om door te werken $\quad 5$

$\begin{array}{ll}2.2 \text { Mogelijkheden om door te werken } & 7\end{array}$

3 Intermediaire effecten 9

3.1 Arbeidsmarkt en inkomen $\quad 9$

3.2 Alternatieven voor langer doorwerken: WW, ZW en WIA 13

3.3 Van WW naar werk 15

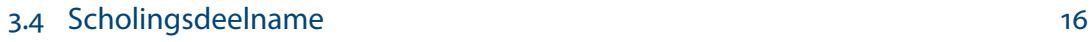

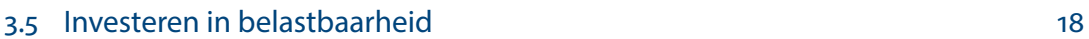

4 Uitkomsten voor werk, inkomen en gezondheid 21

$\begin{array}{lll}4.1 & \text { Arbeidsmarkt en inkomen } & 21\end{array}$

4.2 Inzetbaarheid en gezondheid 26

$\begin{array}{lr}\text { Literatuur } & 29\end{array}$

Appendix A: Cijfers Figuren $\quad 31$

Appendix B: Gebruikte databestanden $\quad 49$

Appendix C: Inhoud van de monitor $\quad 51$ 


\section{Samenvatting}

ROA heeft in opdracht van het Ministerie van SZW de feiten en trends die samenhangen met de AOW-leeftijdsverhoging onderzocht voor de periode 2017-2019. Het onderzoek betreft een update van de AOW-monitor die voor het eerst in 2019 aan het Ministerie van SZW is aangeboden. De monitor is gebaseerd op een conceptueel kader dat uitgaat van een evaluatiemodel waarin diverse fasen worden onderscheiden van het proces waarop de verhoging van de AOW-leeftijd een effect heeft op de uitkomsten die relevant zijn voor het beleidsproces.

De AOW-leeftijd stijgt sinds 2013 stapsgewijs van 65 jaar naar 67 jaar in 2024. Hierdoor is de arbeidsparticipatie van 65-jarigen toegenomen. Ook is er een eerste stijging te zien in de arbeidsparticipatie van 66-jarigen. De AOW-leeftijd is over de tijd steeds belangrijker geworden als norm-leeftijd om met pensioen te gaan. Tegelijkertijd blijven mensen langer in een werkloosheids- en arbeidsongeschiktheidsuitkering. De uitstroomkans naar deze regelingen is voor 65 -jarigen toegenomen als gevolg van de verhoging van de AOW-leeftijd, maar de instroom van WW naar werk stijgt ook. Investeringen in duurzame inzetbaarheid blijven echter achter en de scholingsdeelname is gedaald, vooral door een daling in de cursusdeelname die gefinancierd wordt door werkgevers. Daarnaast is er een toename in het percentage werknemers dat een functieuitbreiding rapporteert. Het percentage werknemers dat promotie heeft gekregen blijft stabiel. De gezondheid van oudere werknemers is niet verslechterd of verbeterd.

Ten opzichte van de vorige monitor zijn er enkele opvallende afwijkingen waarneembaar: 1) Allereerst valt op dat de gemiddelde pensioenleeftijd van zelfstandigen relatief sterk is gestegen sinds $\mathbf{2 0 1 7}$, terwijl de stijging voor werknemers juist is afgevlakt. 2) De piek in de pensioenleeftijd is verschoven van 65 naar 66 jaar, in overeenstemming met de AOW-gerechtigde leeftijd. 3) Gerelateerd aan de vorige trend, vinden wij dat het percentage 65-ers die nog werken significant is gestegen. 4) De voorzichtige daling in de uitstroomkans van werk naar een werkloosheidsuitkering die eerder werd gerapporteerd heeft verder doorgezet tot en met 2019. De uitstroomkans van werk naar WIA blijft stabiel. 5) Het percentage oudere werknemers die denken te kunnen voldoen aan fysieke en psychische eisen is sinds 2017 significant toegenomen 6) Ten opzichte van de vorige monitor is er echter, zoals hierboven reeds opgemerkt, ook sprake van een significante daling in de scholingsdeelname, vooral in de cursussen die door de werkgevers gefinancierd worden. Hoewel deze daling niet alleen beperkt is tot ouderen maar ook waargenomen wordt voor de hele beroepsbevolking, is het zorgwekkend dat werkgevers recentelijk minder zijn gaan investeren in hun personeel. De vraag is in welke mate deze daling in de scholingsdeelname op de langetermijn een negatief effect zal hebben op de duurzame inzetbaarheid. 
Blijven werken

Stijging gemiddelde leetftijd waarop mensen willen doorwerken voor werknemers zet niet door.

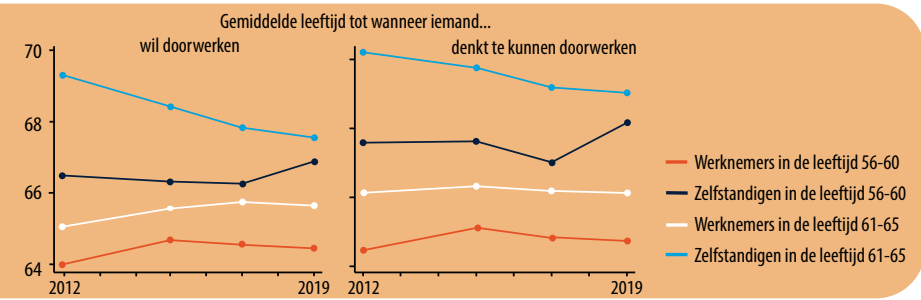

Wat kunnen werkgevers en werknemers doen

\section{Intermediaire effecten}

Steeds later met pensioen

Zowel werknemers als zelfstandigen werken steeds langer door. Vanaf 2017 is de gemiddelde pensioenleeftijd voor zelfstandigen sterk gestegen.

De piekleeftijd van pensioenen schuift steeds meer op naar de AOW-leeftijd, vooral voor werknemers.

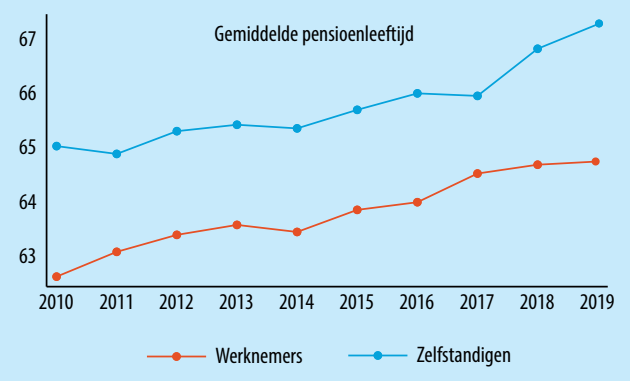

Instroom en uitstroom WW/sociale zekerheid De uitstroomkans van werk naar WW-uitkering voor ouderen neemt af na een initiële stijging. Uitstroom naar een ZW/WIAuitkering is licht gestegen. Het percentage ouderen dat van WW instroomt
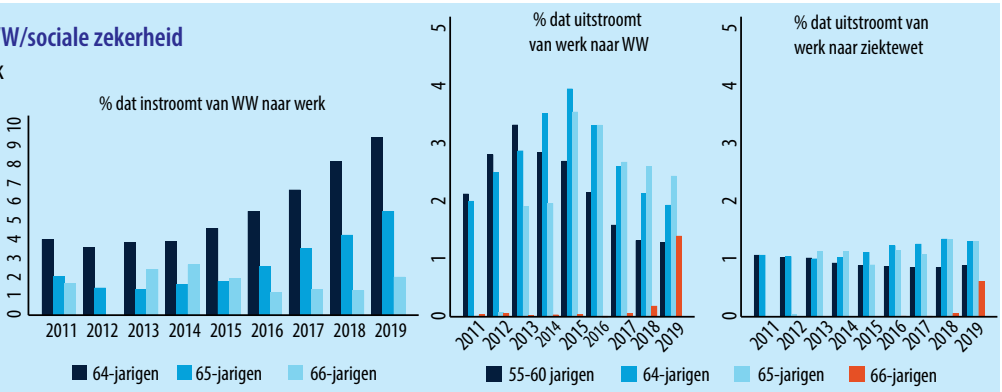

naar werk neemt toe.

a64-jarigen $\quad 65$-jarigen $\quad 66$-jarigen

$\%$ werknemers wat aangeeft dat ze in de laatste 2 jaar...

Beleid op taakbelasting en uitbreiding functies Werknemers zijn tussen 2011-2019 iets vaker van functie verwisseld.

Werknemers zien een uitbreiding in hun functies, wat erop duidt dat taakverlichting niet aan de orde was.
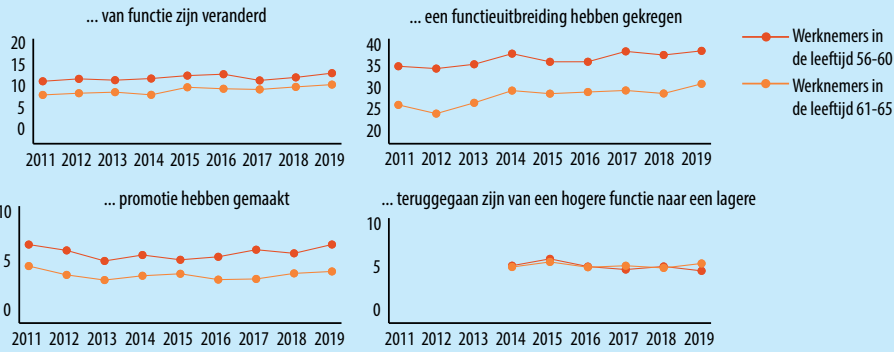

Inzetbaarheid - Scholing daalt Scholingsdeelname is sinds 2016 weer gedaald.

Vooral een daling in de cursussen betaald door de werkgever.
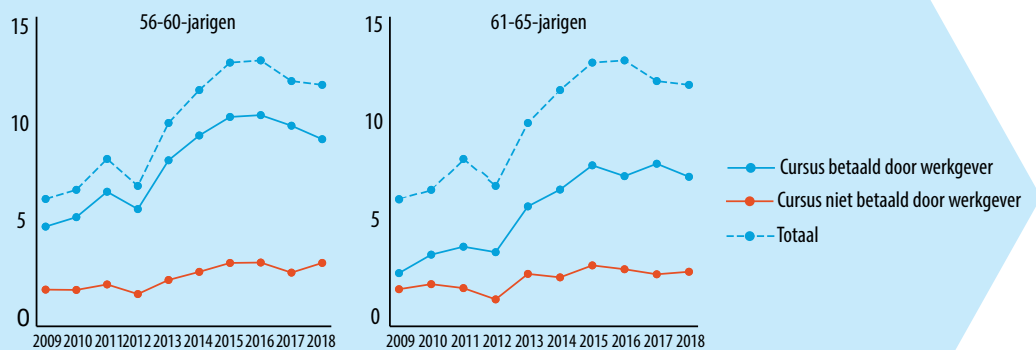


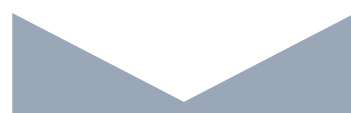

Inkomsten

\section{Wat zijn de effecten op inkomen en arbeidsjaren?}

AOW en pensioen niet meer belangrijkste inkomensbron voor 64 en 65 -jarigen

Arbeidsparticipatie v0or 65 -jarigen is fors toegenomen sinds de verhoging van de AOW leeftijd, terwijl het aandeel van AOW / pensioen als belangrijkste inkomensbron sterk gedaald is.

Het aandeel 65-jarigen dat inkomen ontvangt uit bijstand, WW, ZW of WIA neemt geleidelijk toe tussen 2011 en 2017, en vanaf 2017 vlakt deze toename af.
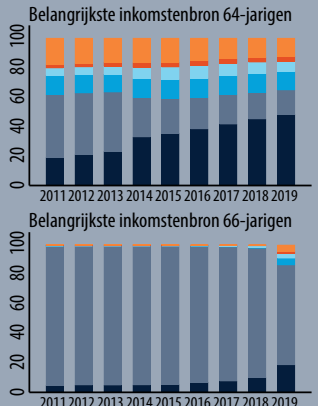

Belangrijkste inkomstenbron 65-jarigen

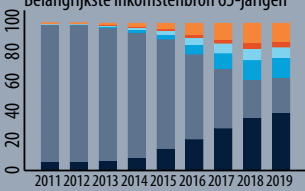

Loondienst

AOW/Pensioen

ZW/WIA

Bijstand/WW

Overig inkomen Geen inkomen

Bruto inkomen blijft stijgen, maar waaiert uit tussen leeftijdsgroepen

Het bruto inkomen stijgt onafgebroken voor 64-, 65- en 66-jarigen.

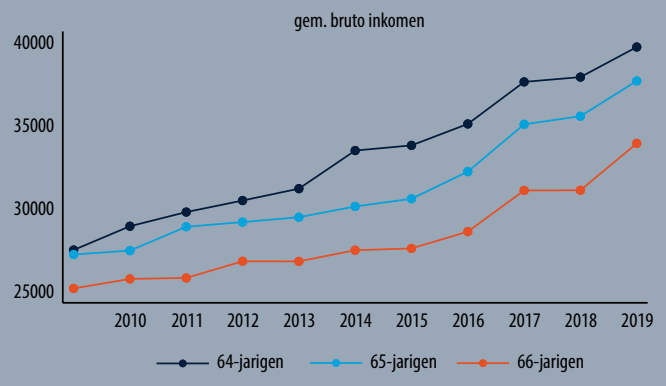

Fysieke en psychische eisen

Hoewel onder werknemers geen patroon te herkennen is wat betreft het aandeel dat aan de fysieke en psychische eisen van het werk kan voldoen, is voor zelfstandigen een negatieve trend zichtbaar tot 2017. Vanaf 2017 stijgt het aandeel voor alle groepen.

Het is onwaarschijnlijk dat deze dalingen te maken hebben met de verhoging van de AOW-leeftijd aangezien het effect kan ook samenhangen met een verandering in de samenstelling van de groep zelfstandigen (toename in het aantal zzp'ers).

$\%$ werknemers dat makkelijk kan voldoen aan...

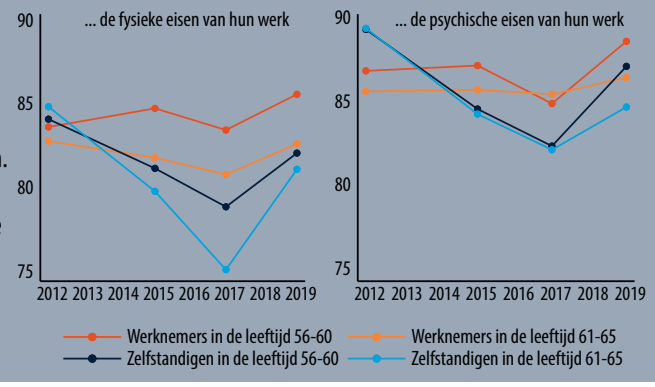

Ervaren gezondheid

De ervaren gezondheid voor ouderen blijft over het algemeen gelijk.

Naar opleidingsniveau treden er echter wel verschillen op. Vooral voor laagopgeleiden laat het percentage goede/zeer goede ervaren gezondheid een neerwaartse trend zien voor zowel $56-60$ als $61-65$ jarigen.
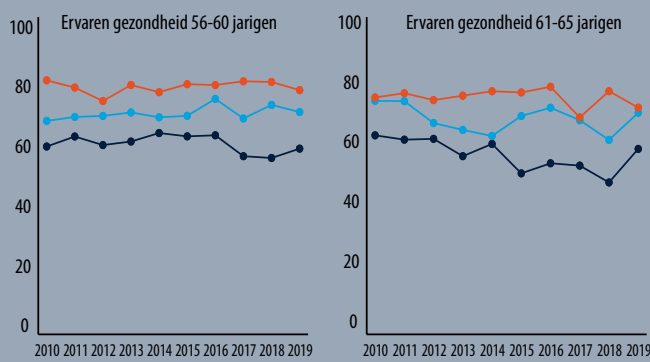

$\longrightarrow$ - Lager opgeleiden $\longrightarrow$ Middelbaar opgeleiden $\longrightarrow$ Hoger opgeleiden

Gezonde levensjaren

Er is sprake van een lichte toename van de gezonde levensverwachting van 65 -jarigen sinds de stijging van de AOW-leeftijd (in mindere mate voor mannen).

Echter, er zijn geen significante verschillen te onderscheiden op het moment dat de AOW-leeftijd is verhoogd.
Levensverwachting in...

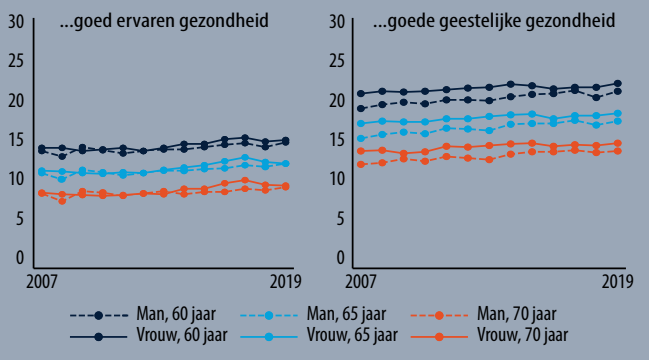





\section{Inleiding: Aanleiding, doel en onderzoeksopzet}

\subsection{Aanleiding}

Sociale zekerheid en pensioensystemen hebben belangrijke effecten op de mate waarin mensen doorwerken, hun besparingskeuzes, gezondheid en hun welzijn. Nederland is daarin geen uitzondering. Door de vergrijzing en ontgroening van de Nederlandse bevolking zijn er in de afgelopen decennia ingrijpende hervormingen geweest van ons pensioenstelsel. VUT en Prepensioenen zijn afgeschaft en de AOW-leeftijd wordt gradueel verhoogd.

Diverse studies laten voor eerdere hervormingen van het pensioenstelsel in Nederland en voor hervormingen in andere landen zien dat veranderingen in de incentivestructuur van het pensioensysteem belangrijke effecten hebben op wanneer mensen met pensioen gaan en op het inkomen na pensionering. ' Bovendien blijken eerdere hervormingen ook sterke negatieve effecten te hebben gehad op de gezondheid van oudere werknemers, productiviteit en het algemeen welzijn. ${ }^{2}$ Deze negatieve effecten kwamen vooral tot stand door sociale vergelijkingen tussen mensen die getroffen waren door de hervormingen met degenen die nog tegen de oude regels met pensioen konden.

Deze eerdere studies hadden echter betrekking op herzieningen van het pensioenstelsel die een abrupte overgang in de pensioenrechten tussen twee opeenvolgende geboortejaren creëerden. Bij de stapsgewijze verschuiving van de AOW-gerechtigde leeftijd is dat niet het geval. Daar heeft ieder cohort een hogere pensioengerechtigde leeftijd dan eerdere geboortejaren, maar een lagere pensioengerechtigde leeftijd dan eerdere cohorten. Dit maakt sociale vergelijkingen veel complexer. Het is daarom niet vanzelfsprekend dat de negatieve effecten op gezondheid en algemeen welzijn die voor eerdere hervormingen van het pensioensysteem zijn gerapporteerd ook zullen worden waargenomen bij de verhoging van de AOW-leeftijd

Het is derhalve relevant om te analyseren of en in hoeverre individuen hun pensioen- en spaargedrag aanpassen in reactie op de stapsgewijze verhoging van de AOW-leeftijd. Daarnaast is het van belang om te onderzoeken hoe welzijn en inzetbaarheid van werknemers die langer moeten doorwerken zich ontwikkelen als gevolg van het verhogen van de AOW-leeftijd. Kan en wil iedereen wel langer doorwerken? En is de stijging van de

$1 \quad$ Het betreft hier studies onder andere van Krueger \& Pischke, 1992; Borsch-Supan, 2000; Coile \& Gruber, 2007; Mastrobuoni, 2009; Blau \& Goodstein, 2010; De Grip et al. 2013; Gelber et al., 2016; Fetter \& Lockwood, 2018; en Lindeboom \& Montizaan 2020.

2 Studies van De Grip et al. 2012; Montizaan et al. 2016 en Montizaan en Vendrik 2014. 
AOW-leeftijd effectief gebleken als instrument om de arbeidsparticipatie van ouderen te verhogen?

\subsection{Doel}

Om deze vragen te beantwoorden heeft het Ministerie van Sociale Zaken en Werkgelegenheid in 2019 een eerste onderzoek laten uitvoeren naar de effecten van de verhoging van de AOW-leeftijd. Het onderzoek omvat een monitor die feiten en trends die samenhangen met de AOW-leeftijdsverhoging in beeld bracht voor de periode 2007-2017. ${ }^{3}$

Het Ministerie van Sociale Zaken en Werkgelegenheid wil naar aanleiding van de in 2019 uitgevoerde beleidsdoorlichting van artikel 8 Oudedagsvoorziening van de SZW begroting deze monitor voortzetten door de feiten en trends die samenhangen met de AOW-leeftijdsverhoging en het langer doorwerken de komende vijf jaar jaarlijks in beeld te brengen. Doel is om de ontwikkelingen in arbeidsmarkt, inkomen, inzetbaarheid en gezondheid van 55 tot 75 jarigen periodiek in kaart te brengen.

In deze rapportage worden de resultaten besproken van de 2020 update van de AOW-monitor. In de monitor wordt de periode 2007-2019 in beeld gebracht voor de groep 55-75-jarigen die op 31 december van elk jaar in Nederland wonen.

\subsection{Onderzoeksopzet}

Voor de monitor is een conceptueel kader ontwikkeld die in Figuur 1 is samengevat. Het conceptueel kader gaat uit van een evaluatiemodel waarin diverse fasen worden onderscheiden van het proces waarop de verhoging van de AOW-leeftijd een effect heeft op de uitkomsten die relevant zijn voor het beleidsproces.

1. In de eerste fase geeft de verhoging van de AOW-leeftijd werkenden een financiële prikkel om door te werken doordat pensioneren op deze leeftijd nu volledig gefinancierd moet worden uit de tweede en derde pijler van het pensioensysteem. En ook werkgevers ondervinden een prikkel omdat hun werknemers langer in dienst zullen blijven doordat de contracten voor onbepaalde tijd veelal automatisch doorlopen tot de AOW-leeftijd.

2. Door deze prikkels zullen zowel werknemers als werkgevers hun voorkeuren moeten aanpassen aan de nieuwe situatie. Dit is fase twee van het proces. Het proces waarop deze voorkeuren veranderen hangt tevens af van de mogelijkheden die zij hebben. De prikkel voor werkenden en werkgevers om langer door te werken werkt uitslui-

3 Het rapport is in 2020 verschenen: Ministerie van Sociale Zaken en Werkgelegenheid / SEO. (2020) Effect verhoging AOW-leeftijd. Resultaten monitor-en literatuuronderzoek-Rapport-Kennisplatform Werk en Inkomen. 
tend effectief als werkenden ook in staat zijn om door te werken en ook de motivatie hebben om aan de slag te blijven. Dit wordt enerzijds beïnvloed door de belastbaarheid en inzetbaarheid van het individu, maar ook door de belasting van het werk.

3. In de derde fase kunnen werknemers en werkgevers actie ondernemen om hun voorkeuren voor langer doorwerken of het verhogen van de belastbaarheid / verlagen van de werkbelasting in de praktijk te brengen (intermediaire effecten). Degenen die willen doorwerken zullen gedurende hun loopbaan bijvoorbeeld meer kunnen gaan investeren in het vergroten van hun belastbaarheid en inzetbaarheid, bijvoorbeeld door het volgen van scholing. Daarnaast is het mogelijk dat werknemers die niet langer willen doorwerken ervoor kiezen om meer te gaan (bij)sparen voor hun pensioen. En de mogelijkheid bestaat dat werknemers alternatieve routes opzoeken om alsnog vervroegd uit te treden. Als werkenden ziek zijn en derhalve niet kúnnen doorwerken, dan zullen zij instromen in de Ziektewet (ZW) en/of de WIA. En bij werkloosheid bestaat de kans dat zij instromen in de WW of bijstand. De investeringen in het menselijk kapitaal zullen vervolgens over de tijd de mogelijkheden om langer door te werken verbeteren, terwijl uitstroom uit werk naar ZW, WIA of WW en extra pensioenbesparingen juist de mogelijkheden om door te werken verslechteren. Dit betekent dat er sprake is van een dynamisch proces waarin de context waarin mensen in fase twee een keuze maken op basis van een afweging tussen wensen en mogelijkheden dus ook wordt beinvloed door keuzes die gemaakt zijn in eerdere jaren.

4. De vierde en laatste fase omvat uiteindelijk de beleidsuitkomsten. Het uiteindelijke doel van de verhoging van de AOW-leeftijd was en is om de arbeidsparticipatie van ouderen te vergroten. De AOW-lasten zullen dan gaan dalen. Tegelijkertijd zijn er neveneffecten mogelijk zoals een hoger beroep op WW/WIA en bijstand, en potentiële inkomenseffecten.

Relevant hierbij is om op te merken dat de effecten van de AOW-leeftijdsverhoging verschillend (kunnen) uitpakken voor verschillende groepen ouderen. Inkomen en opleidingsniveau spelen hierbij een belangrijke rol. Uit eerder onderzoek weten we immers dat lager opgeleiden vaker doorwerken vanwege financiële noodzaak, terwijl hoger opgeleiden juist doorwerken omdat zij intrinsiek gemotiveerd zijn om door te werken en ook vaker hiertoe gezondheidstechnisch in staat zijn. Wensen en mogelijkheden kunnen dus substantieel verschillen tussen deze groepen.

\subsection{Opzet rapportage}

Het rapport volgt de structuur van het conceptueel kader in figuur 1. Hoofdstuk 2 bespreekt de trends in de wensen en mogelijkheden die werknemers hebben om langer door te werken. Hoofdstuk 3 laat de trends zien in de intermediaire effecten en hoofdstuk 4 bespreekt de uitkomstmaten. Gedetailleerde informatie over de monitor en verdere achtergrondinformatie zijn opgenomen in de bijlagen. 


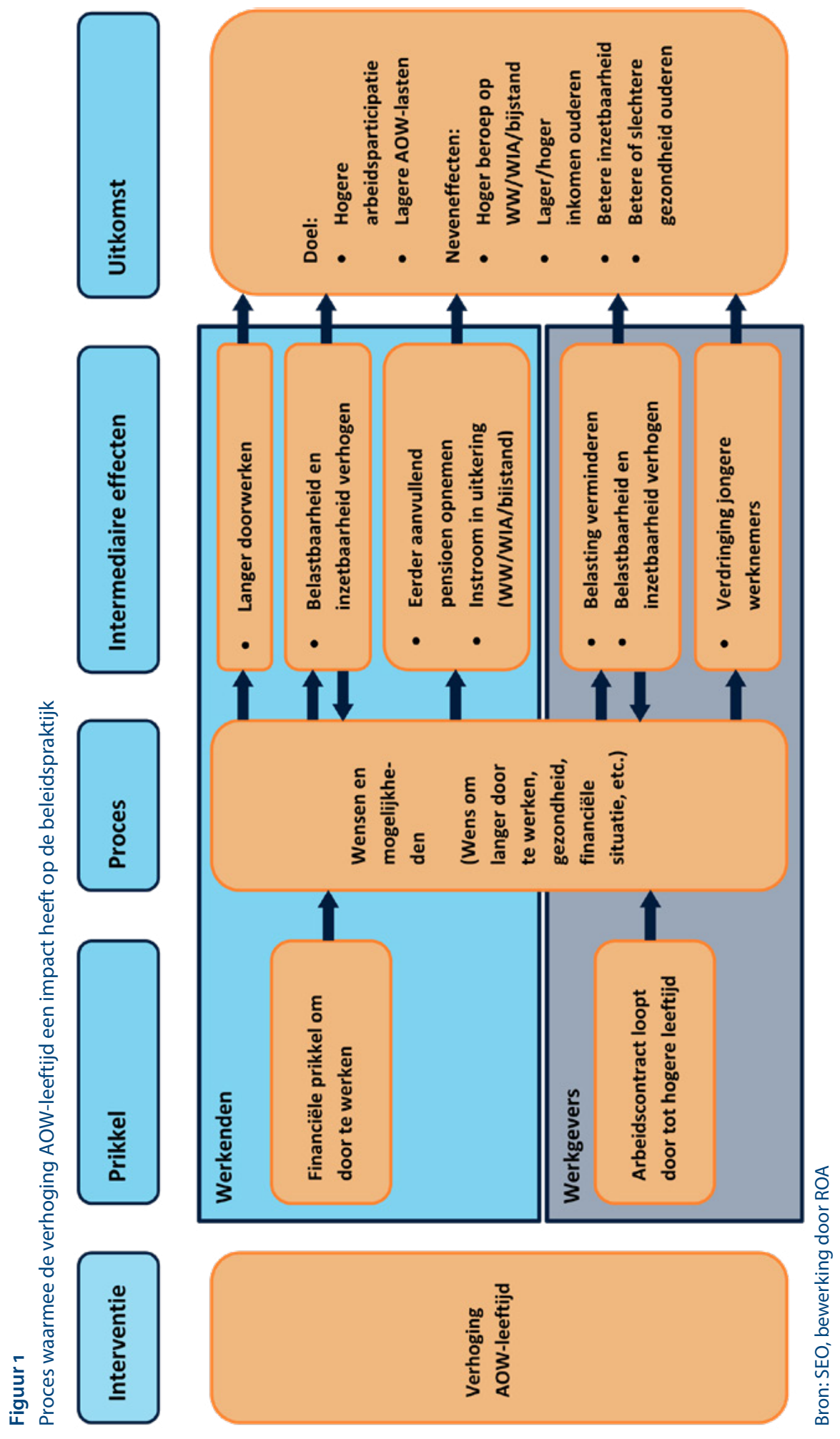




\section{Wensen en mogelijkheden}

De AOW-leeftijd komt stapsgewijs steeds hoger te liggen. Dit geeft werkenden een financiële prikkel om steeds langer te blijven werken. Maar de effectiviteit van deze prikkel is in de eerste plaats afhankelijk van de wensen die werknemers hebben ten aanzien van hun pensioen. Het is aannemelijk dat de financiële prikkels de wens om langer door te werken vergroot, maar op zowel maatschappelijk als persoonlijk niveau bestaat er ook weerstand tegen het verhogen van de AOW-leeftijd en er zullen grenzen zitten aan de effectiviteit van de prikkel. Bovendien, werknemers moeten ook de mogelijkheid hebben om door te kunnen werken: zijn werknemers daadwerkelijk ook in staat om tot een steeds hogere leeftijd aan het werk te blijven? Het risico op baanverlies of arbeidsongeschiktheid speelt hierbij een grote rol. In dit hoofdstuk worden de ontwikkelingen rondom deze wensen en mogelijkheden besproken.

\subsection{Wensen om door te werken}

De AOW-leeftijd gaat sinds 1 januari 2013 stapsgewijs omhoog. Tot 2015 steeg de AOW leeftijd jaarlijks met 1 maand. Sinds 1 januari 2016 gebeurt dat versneld: in 2016, 2017 en 2018 waren de stappen drie maanden, en in 20194 maanden. Voor het pensioenakkoord in 2019 was de idee dat deze stappen van 4 maanden zouden worden doorgezet tot en met 2021, waarna de AOW-leeftijd vervolgens gekoppeld zou worden aan de levensverwachting. Het pensioenakkoord bracht hier verandering in met de zogenaamde Wet temporisering verhoging AOW-leeftijd. Met deze wet werd bewerkstelligd dat de AOW-leeftijd tot en met 2021 bevroren werd op 66 jaar en vier maanden. Vervolgens stijgt de AOW-leeftijd in 2022 naar 66 jaar en zeven maanden, in 2023 naar 66 jaar en tien maanden en in 2024 en 2025 naar 67 jaar. In de oude situatie steeg de AOW-leeftijd al in 2021 naar 67 jaar.

Desalniettemin is duidelijk dat sinds 2012 de AOW-gerechtigde leeftijd is gestegen met ruim 1 jaar en 4 maanden. Voor veel huishoudens betekent dit dan ook een grote financiële prikkel om langer door te werken. De vraag is hoe dit de wensen van werkenden heeft beïnvloed.

\section{Trends in de data}

Figuur 2 laat de trend zien in hoe werknemers de volgende vraag hebben beantwoord: 'Tot welke leeftijd wilt u doorgaan met werken?'. Daarbij wordt onderscheid gemaakt tussen werknemers en zelfstandigen en twee leeftijdsgroepen ( 55 tot en met 60 jaar en 61 tot en met 65 jaar). Uit de figuur blijkt dat onder werknemers de wens om door te werken licht gestegen is in de periode tussen 2012 tot 2019. In de leeftijdsklasse 56 tot 60 jaar is de 
gewenste uittreedleeftijd echter blijven hangen rond 64,5 jaar. De sterkste stijging is zichtbaar voor de leeftijdsklasse 61 tot 65 jaar, van 65 jaar in 2012 naar 66 jaar in 2019. De wensen voor de 61 en 65 jarigen lopen dus in de pas met de verhoging van de AOW-leeftijd.

Tabel 1

Stapsgewijze verhoging van de AOW-leeftijd voor en na de invoering van de Wet temporisering verhoging AOW-leeftijd

\begin{tabular}{ll|l} 
Jaar & AOW-leeftijd voor pensioenakkoord in 2019 & AOW-leeftijd na pensioenakkoord in 2019 \\
\hline 2013 & $65+1$ maand & \\
2014 & $65+2$ maanden & \\
\hline 2016 & $65+6$ maanden & \\
\hline 2017 & $65+9$ maanden & \\
\hline 2018 & 66 & $66+4$ maanden \\
\hline 2019 & $66+4$ maanden & $66+4$ maanden \\
\hline 2020 & $66+8$ maanden & $66+4$ maanden \\
\hline 2021 & 67 & $66+7$ maanden \\
\hline 2022 & $67+3$ maanden & $66+10$ maanden \\
\hline 2023 & $67+3$ maanden & 67 \\
\hline 2024 & $67+3$ maanden & 67 \\
\hline 2025 & $67+3$ maanden & \\
\hline
\end{tabular}

Voor zelfstandigen van 61-65 jaar is de wens om door te werken echter afgenomen. Hoewel 61-65 jarige zelfstandigen in 2012 gemiddeld genomen nog bereid waren om tot hun 69ste door te werken, is dit in 2019 gedaald naar een gewenste uittreedleeftijd onder de 68. De gewenste uittreedleeftijd onder zelfstandigen van 56-60 jaar is echter over de hele periode onder de 67 jaar blijven hangen en is sinds 2017 licht gestegen. De daling om door te werken onder zelfstandigen heeft echter waarschijnlijk weinig te maken met de verhoging van de AOW-leeftijd. Zelfstandigen wensen nog steeds ruim voorbij de AOW-gerechtigde leeftijd uit te te treden en wensen ook nog steeds langer door te werken dan werknemers. Het verschil in wensen tussen zelfstandigen en werknemers is wel beduidend minder groot geworden over het verloop van de tijd.

Tabel A1 laat verder zien dat er geen verschillen zijn in de wensen voor doorwerken tussen lager, middelbaar en hoger opgeleide werknemers. Wel valt er een verschil te observeren bij de zelfstandigen wat betreft het opleidingsniveau. Des te hoger het opleidingsniveau, des te langer een zelfstandige wil doorwerken. De daling in de gewenste uittreedleeftijd onder 61-65 jarigen was het sterkst onder de zelfstandigen met een middelbaar opleidingsniveau. 


\section{Figuur 2}

Ouderen willen in 2019 niet veel langer doorwerken dan in 2012 en denken over het algemeen dat ook niet te kunnen

\section{Gemiddelde leeftijd tot wanneer iemand...}
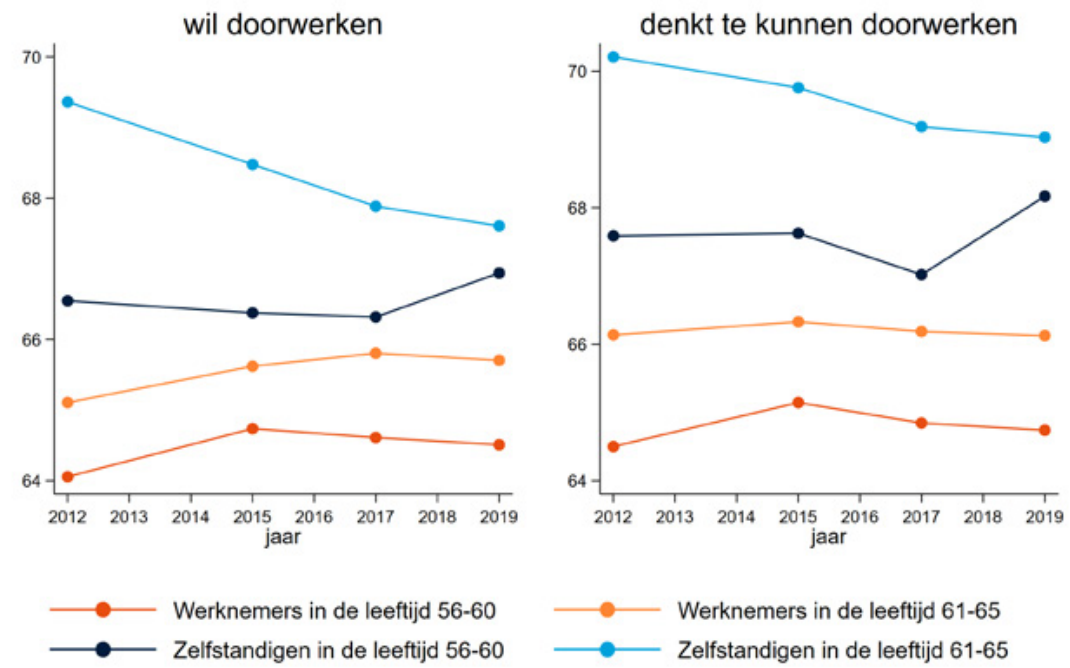

Bron: CBS Microdata. Bewerking door ROA

\subsection{Mogelijkheden om door te werken}

Het is een grote zorg onder werkgevers, werknemers en beleidsmakers of mensen hun werk wel fysiek kunnen volhouden. In hoeverre zullen gezondheidsklachten geassocieerd met leeftijd een rol gaan spelen voor inzetbaarheid van werknemers met gezondheidsklachten?

\section{Trends in de data}

De rechter helft van Figuur 2 laat de gemiddelde leeftijd zien tot welke werknemers verwachten door te kunnen werken. Het blijkt dat deze leeftijd voor werknemers in de leeftijdsklasse 56-65 jaar vrijwel onveranderd gebleven is sinds 2012. Voor zelfstandigen vinden we eenzelfde patroon als voor de gewenste pensioenleeftijd. Onder de oudere groep zelfstandigen van 61-65 jaar verwacht men in 2019 een jaar minder lang door te kunnen werken dan in 2012: van een leeftijd van 70 jaar naar 69 jaar. Opvallend is dat zelfstandigen van 56-60 jaar juist langer denken te kunnen doorwerken van een leeftijd van 67 jaar in 2017 naar 68 jaar in 2019. Dit is een relatief forse stijging voor een korte periode, en staat dus in contrast met de ontwikkeling binnen de oudere leeftijdsklasse. 
Uit Tabel A1 blijkt verder dat hoogopgeleiden een jaar langer denken te kunnen doorwerken dan laagopgeleiden en dat dit verschil over de tijd niet verandert. De sterke daling onder zelfstandigen in de leeftijdscategorie 61-65 jaar komt vooral doordat laagopgeleide zelfstandigen verwachten minder lang te kunnen doorwerken (van 69,5 naar 66,3 jaar). De stijging in de leeftijd tot wanneer 56-60 jarige zelfstandigen denken door te kunnen werken is daarentegen het sterkst onder laagopgeleiden. 


\section{Intermediaire effecten}

Dit hoofdstuk gaat in op de acties die volgen op de aanpassing in de wens om door te werken als gevolg van de verhoging van de AOW-leeftijd. Een voorbeeld van zo'n actie is dat werkenden besluiten later met pensioen te gaan. Anderzijds kunnen werkenden ook besluiten om meer te gaan sparen in de tweede en derde pijler van het pensioensysteem of ze kunnen alsnog uittreden op de voormalige AOW-leeftijd tegen een lager pensioeninkomen dat gefinancierd wordt uit de tweede pijler van het pensioensysteem. Indien werkenden echter voor langer doorwerken kiezen, vergt dit ook actie om ouderen inzetbaar te houden. Indien werkenden namelijk langer moeten doorwerken maar problemen ervaren met hun inzetbaarheid en belastbaarheid, kan dat gevolgen hebben voor de uitstroomkans naar de Ziektewet en/of WIA, of naar de WW/bijstand wanneer ze volgens de werkgever onvoldoende productief zijn. Om te voorkomen dat ouderen in een arbeidsongeschiktheids- of werkloosheidssituatie belanden, zullen werkenden en werkgevers moeten investeren in inzetbaarheid en de belastbaarheid. Dit gaat vaak gepaard met trainingen of scholingsdeelname die ervoor moeten zorgen dat oudere werkenden hun kennis en vaardigheden up-to-date houden. Verder kunnen werkgevers andere maatregelen treffen om de werkbelasting te verlagen, zoals het inzetten van taakverlichting of het bieden van meer flexibele werkuren aan ouderen.

Deze acties (oftewel intermediaire effecten) zijn allemaal onderdeel van het proces die de effectiviteit bepaalt van het effect van de verhoging van de AOW-leeftijd op de arbeidsparticipatie van ouderen en de AOW-lasten voor de samenleving.

\subsection{Arbeidsmarkt en inkomen}

Door het verhogen van de AOW-gerechtigde leeftijd krijgen ouderen een prikkel om langer door te blijven werken. De vraag is of zij dit ook daadwerkelijk doen?

\section{Trends in de data}

Zowel werknemers als zelfstandigen zijn langer door gaan werken na 2010. Tot 2017 was de toename in de gemiddelde pensioenleeftijd groter voor werknemers dan voor zelfstandigen. De afschaffing van het prepensioen voor werknemers in 2006 heeft ervoor gezorgd dat in de opvolgende jaren de gemiddelde pensioenleeftijd voor werknemers fors is gestegen. Het gevolg hiervan is dat er een verschil is ontstaan in de toename van de gemiddelde pensioenleeftijd tussen werknemers en zelfstandigen. Tussen 2010 en 2012 is de gemiddelde pensioenleeftijd voor werknemers met 1 jaar gestegen. Sinds 2012 stijgt de gemiddelde pensioenleeftijd van werknemers en werkgevers verder. Dit kan onder andere komen doordat zowel werknemers als zelfstandigen te maken hebben 
gekregen met de stapsgewijze verhoging van de AOW-leeftijd. Echter, ook de effecten van de eerdere hervormingen, zoals de afschaffing van prepensioen in het Aangepast pensioenstelsel zullen hier deels nog voor verantwoordelijk zijn. In 2017 bedroeg de gemiddelde pensioenleeftijd 64,5 jaar voor werknemers en 66 jaar voor zelfstandigen.

Van 2017 tot 2019 is de gemiddelde pensioenleeftijd sterk toegenomen voor zelfstandigen: binnen twee jaar tijd stijgt de gemiddelde leeftijd met bijna 16 maanden, naar 67,3 jaar. Voor werknemers is er daarentegen een afremming waarneembaar in de stijging van de gemiddelde pensioenleeftijd.

\section{Figuur 3}

De gemiddelde pensioenleeftijd stijgt

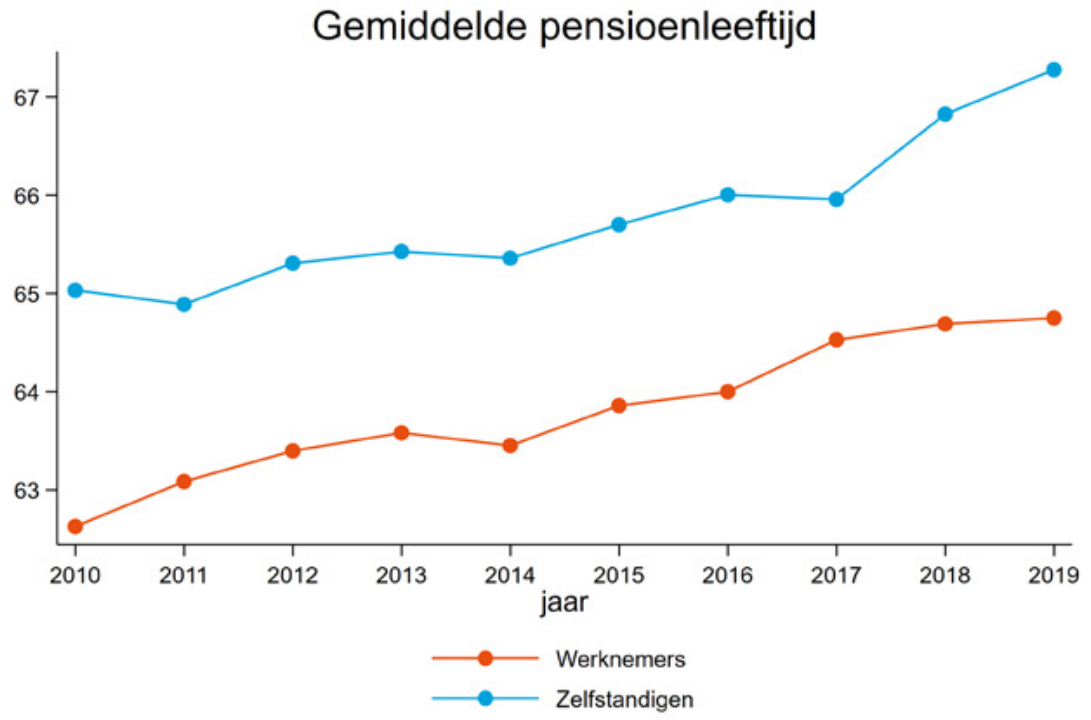

Bron: CBS Microdata. Bewerking door ROA

Figuur $A_{1}$ in Appendix A laat verder zien dat de gemiddelde pensioenleeftijd voor alle inkomensklassen geleidelijk is gestegen. Over het algemeen gaan ouderen uit lagere inkomensklassen later met pensioen. Dit geldt vooral voor werknemers, waarbij in 2019 een jaar verschil zit in de gemiddelde pensioenleeftijd tussen de laagste inkomensklasse (tot minimumloon, gemiddeld 64,8 jaar) en de hoogste inkomensklasse (boven 2 keer modaal, gemiddeld 63,8 jaar). Wat de zelfstandigen betreft ligt de gemiddelde pensioenleeftijd voor hogere inkomensklassen ook steeds onder die van lagere inkomensklassen. Dit komt omdat ouderen uit hogere inkomensklassen eerder geneigd zijn met pensioen te gaan op de pensioengerechtigde leeftijd. De sterke toename van de gemiddelde pensioenleeftijd van zelfstandigen tussen 2010 en 2019 valt echter niet toe te schrijven aan een forsere toename van bijvoorbeeld lagere inkomensklassen op de arbeidsmarkt. 
Zelfstandigen in alle inkomensklassen zagen in deze periode namelijk een toename van ongeveer 2,5 jaar in de gemiddelde pensioenleeftijd. Het is dus ook onwaarschijnlijk dat de forse toename in de gemiddelde pensioenleeftijd onder zelfstandigen de laatste paar jaar werd gedreven door een toename van zzp'ers op de arbeidsmarkt.

Naast de gemiddelde pensioenleeftijd zijn de frequenties van pensioenleeftijden van belang. Hierdoor wordt zichtbaar op welke leeftijden de meeste mensen met pensioen gaan, oftewel wat de 'piekleeftijden' zijn. Indien de financiële prikkel van de verhoging van de AOW-leeftijd een causaal effect zou hebben op de pensioenleeftijd, zouden we vooral veranderingen verwachten op de piekleeftijden rondom de AOW-leeftijd. Figuur 4 laat de dichtheid van de frequenties zien voor pensioenleeftijden van zowel werknemers als zelfstandigen. In 2010 en de paar opvolgende jaren is de frequentie van pensioenleeftijden voor werknemers gematigd verdeeld tussen 61 en 65 jaar. Omdat ze nog recht hadden op prepensioen gingen veel werknemers met pensioen als zij 62 jaar en 3 maanden werden tegen een vervangingsratio van ongeveer $70 \%$ van hun inkomen. Hierna is sprake van een verschuiving van de piekleeftijd naar 65 jaar: deze leeftijd heeft tot en met 2016 de hoogste dichtheid. Mensen die geen recht hadden op prepensioen hebben dus vooral de AOW-leeftijd als de nieuwe norm genomen voor hun pensioen. Pensioen na 65 jaar komt relatief weinig voor tot 2016, hoewel voorzichtig de opkomst is te zien van een piek op 66 jaar.

Voor zelfstandigen zien we dat in de periode 2010-2016 eveneens een piek is te zien op 65 jaar en dat zij veel minder vaak vervroegd uittreden dan werknemers. Daarnaast valt op dat zij relatief vaak door gaan na de AOW-gerechtigde leeftijd. Dit komt omdat zij in tegenstelling tot veel werknemers niet gebonden zijn aan CAO-afspraken die het contract beëindigen zodra men de AOW-gerechtigde leeftijd heeft bereikt.

2016 en 2017 zijn belangrijke jaren wat de piekleeftijden van het pensioen betreft, voor zowel werknemers als zelfstandigen. Tussen deze jaren slaat de piekleeftijd voor beide groepen om van 65 naar 66 jaar. Dit suggereert dus dat er sprake is van een causale impact van de verhoging van de AOW-leeftijd op de pensioenleeftijd. Immers in deze periode verschuift de AOW-leeftijd langzaam van 65 jaar naar 66 jaar. De piek op 66 jaar is vervolgens in 2018 en 2019 steeds duidelijker zichtbaar. Voor werknemers geldt dat zij nauwelijks doorwerken voorbij 66 jaar. Voor zelfstandigen zien we in 2019 al dat de piek op 66 jaar iets minder sterk is en worden de eerste tekenen van een omslag van de piekleeftijd naar 67 jaar al zichtbaar. Samenvattend kan worden gesteld dat de pensioenleeftijd steeds meer is opgeschoven naar de AOW-leeftijd en vervolgens dat deze met de verhoging van deze leeftijd mee beweegt, met name voor werknemers. Zelfstandigen hebben meer flexibiliteit in wanneer zij met pensioen gaan, maar gaan ook vaak op de AOW-leeftijd met pensioen of treden zelfs later uit. 
Figuur 4

Piekleeftijden in pensionering
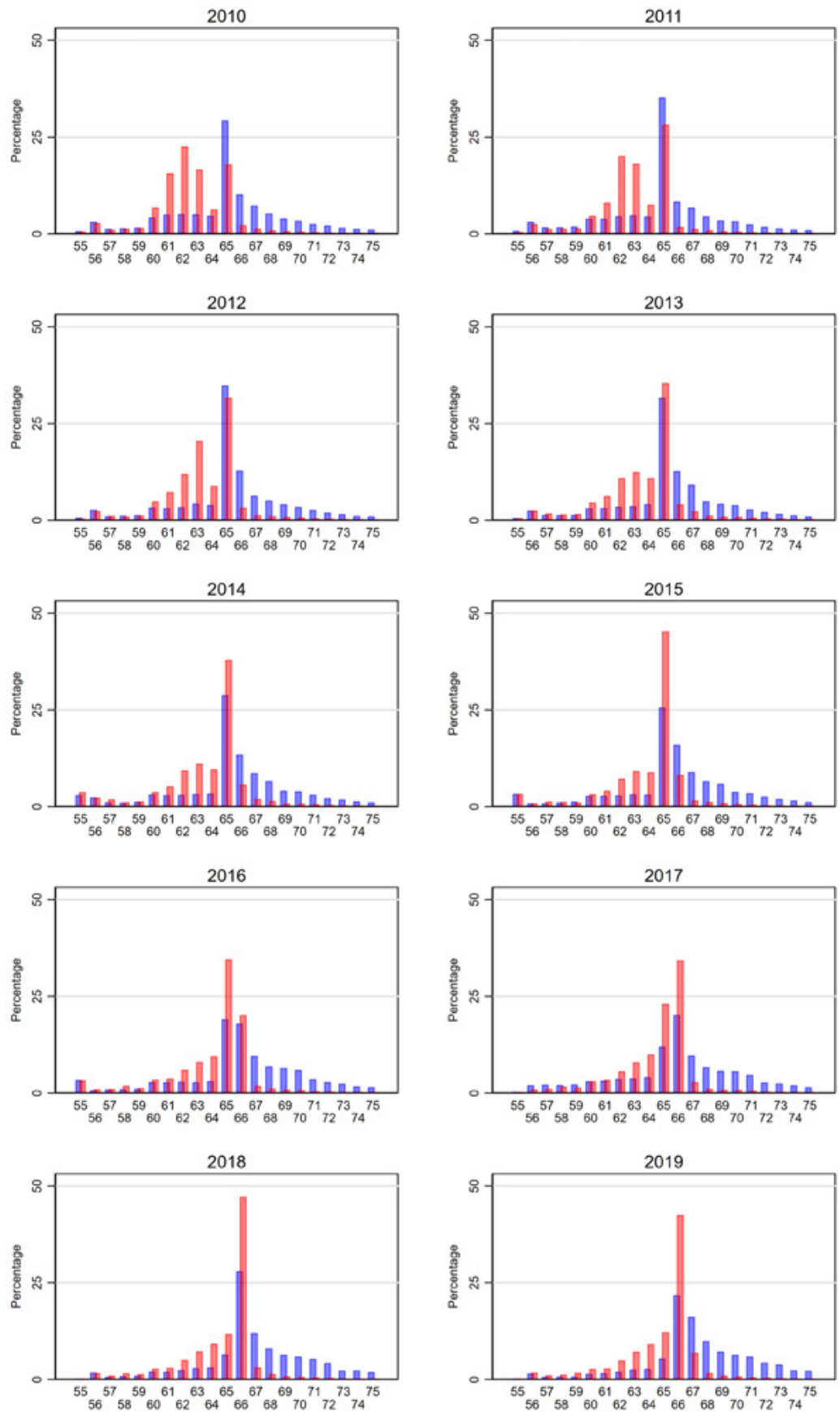

Zelfstandige

Werknemer 


\subsection{Alternatieven voor langer doorwerken: WW, ZW en WIA}

Er zitten grenzen aan de effectiviteit van de prikkel die uitgaat van de verhoging van de AOW-leeftijd op het langer doorwerken. Niet elke persoon zal de mogelijkheid hebben om door te kunnen werken. Door de financiële prikkel om door te werken als gevolg van het verhogen van de AOW-leeftijd gepaard met de maatregelen die werkgevers treffen om ouderen inzetbaar te houden en doordat de vereisten voor arbeidsongeschiktheidsuitkeringen zijn aangescherpt, zal er naar verwachting maar een beperkte toename zijn van ouderen die werkloos of arbeidsongeschikt worden (Staubli en Zweimuller, 2013; Lalive en Staubli, 2014). We onderzoeken dit verder in Figuur 5 waarin de uitstroom van werk naar de WW en de ziektewet wordt getoond voor 55-60 jarigen, 64, 65 en 66 jarigen. Relevant om hierbij op te merken is dat bij nieuwe betalingen van een WIA-uitkering nog geen onderscheid tussen uitkeringen als voorschot en definitieve WIA-uitkeringen wordt gemaakt. Er zijn allerlei redenen waarom een aanvraag niet binnen de gestelde wettelijke termijn afgehandeld kan worden en een voorschot verstrekt wordt. Een reden kan bijvoorbeeld zijn dat de benodigde stukken niet op tijd geleverd zijn door de klant. Er kunnen ook uitvoeringsredenen zijn (bijvoorbeeld een tekort aan artsen). Hierdoor wordt de uitstroom naar de WIA altijd licht overschat (Berendsen en Rijnsburger 2021).

Figuur 5

Uitstroomkans van werk naar werkloosheids- of arbeidsongeschiktheidsuitkering
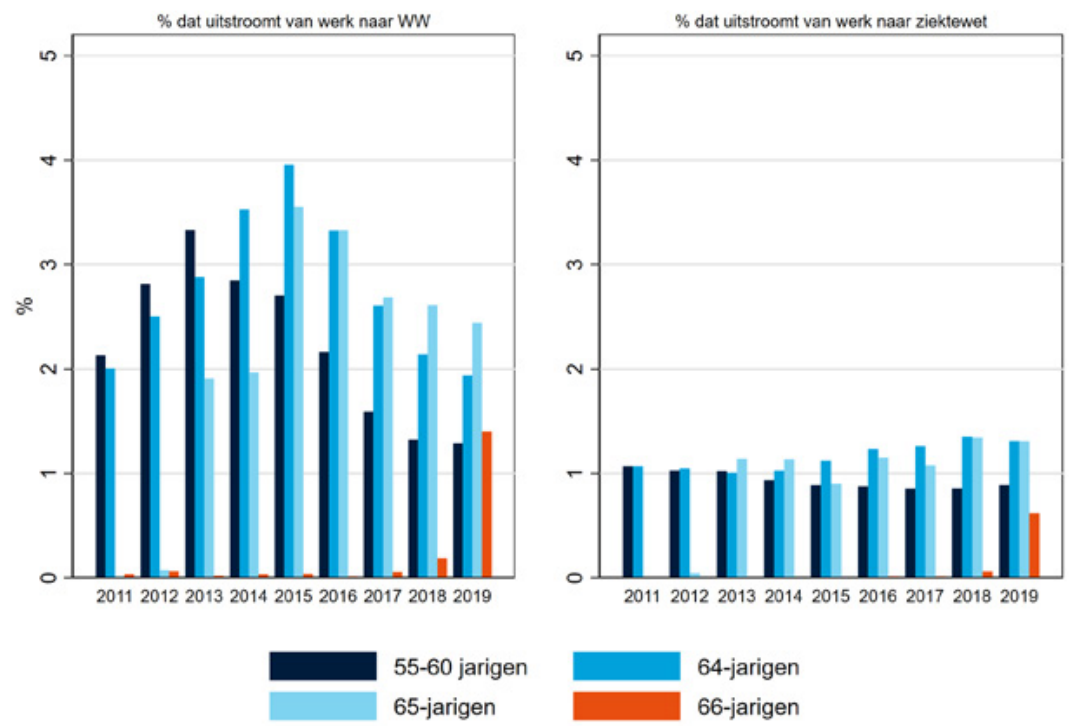

Bron: CBS Microdata. Bewerking door ROA 


\section{Trends in de data}

Het percentage dat uitstroomt van werk naar WW is sinds de verhoging van de AOW-leeftijd in eerste instantie toegenomen. In 2015 stroomde gemiddeld $4 \%$ van de 64-jarige werknemers door naar de WW of bijstand, en voor 65-jarigen was dat gemiddeld 3,6\%. Sinds 2016 is deze kans echter langzaam aan het afnemen, naar 2,4\% voor 65-jarigen en 1,4\% voor 64-jarigen in 2019. Dit is lager dan de uitstroomkansen in 2013. Echter, de uitstroomkans van 64- en 65-jarigen is sinds 2013 significant hoger dan voor 55-60-jarigen.

De kans dat 55-60 jarigen uitstromen van werk naar een ZW/WIA-uitkering is tussen 2011-2017 gedaald om vervolgens vanaf 2018 weer licht toe te nemen. De kans ligt voor deze periode onder de $1 \%$. Hoewel de kans op uitstroom naar een ZW/WIA-uitkering dus beperkt is, is deze kans wel lichtelijk hoger voor 64- en 65-jarigen. Dit kan komen doordat deze cohorten vanwege hun leeftijd in toenemende mate met gezondsproblemen worden geconfronteerd. De geobserveerde toename in deze kans sinds 2013 is een logische consequentie van de AOW-leeftijd verhoging. In 2019 is de kans dat iemand van 65 jaar uitstroomt van werk naar een ZW/WIA-uitkering 1,3\%. Deze kans is identiek voor 64-jarigen, terwijl voor 66-jarigen de kans iets kleiner is: $0,6 \%$, waarschijnlijk omdat 66-jarigen met pensioen gaan voordat zij in aanmerking komen voor een $\mathrm{ZW}$-uitkering. De stijging voor de uitstroom van 64 en 65 jarigen naar een ZW/WIA-uitkering is dus zeer minimaal gestegen en na 2018 is de uitstroomkans ongeveer gelijk gebleven. Dat er geen verdere stijging is, kan gerelateerd zijn aan het niet verhogen van de AOW-leeftijd in het afgelopen jaar.

We hebben de cijfers over de uitstroom naar de WW en de ziektewet ook uitgesplitst naar opleidings- en inkomensniveau. Gekeken naar opleiding (zie Appendix A) is sinds 2015 dezelfde negatieve trend in de uitstroom naar de WW zichtbaar voor elk opleidingsniveau. De uitstroomkans voor hoger opgeleiden daalt echter iets minder hard en komt iets boven de uitstroomkans voor laagopgeleiden te liggen. Wordt gekeken naar inkomensniveau (zie Appendix A), dan komt dezelfde neerwaartse trend sinds 2015 naar voren voor alle inkomensklassen, zonder al te grote verschillen tussen deze klassen. Opvallend is enkel de hoogste inkomensklasse (2 keer modaal of hoger): deze klasse heeft in 2019 een uitstroomkans van 2,4\%, wat gelijk is aan de uitstroomkans voor de klasse minimumloon tot modaal inkomen.

Wat betreft het de uitsplitsing van de uitstroom naar de WIA naar opleiding valt op dat uitstroomkans van werk naar ZW/WIA het hoogste is voor lager opgeleiden en deze sinds 2014 het meeste is toegenomen voor middelbaar opgeleiden van 65 jaar (van 0,9\% naar 1,9\%). Ook zijn er verschillen tussen inkomensklassen (zie appendix): lagere inkomens (modaal of lager) hebben gemiddeld een hogere uitstroomkans, maar er is geen groot verschil tussen 64- en 65-jarigen. Net zoals bij de uitstroom naar de WW, zien we dat de uitstroom naar de ZW/WIA lager is voor 56-60 jarigen. 
Figuur 6

Instroomkans uit WW naar werk

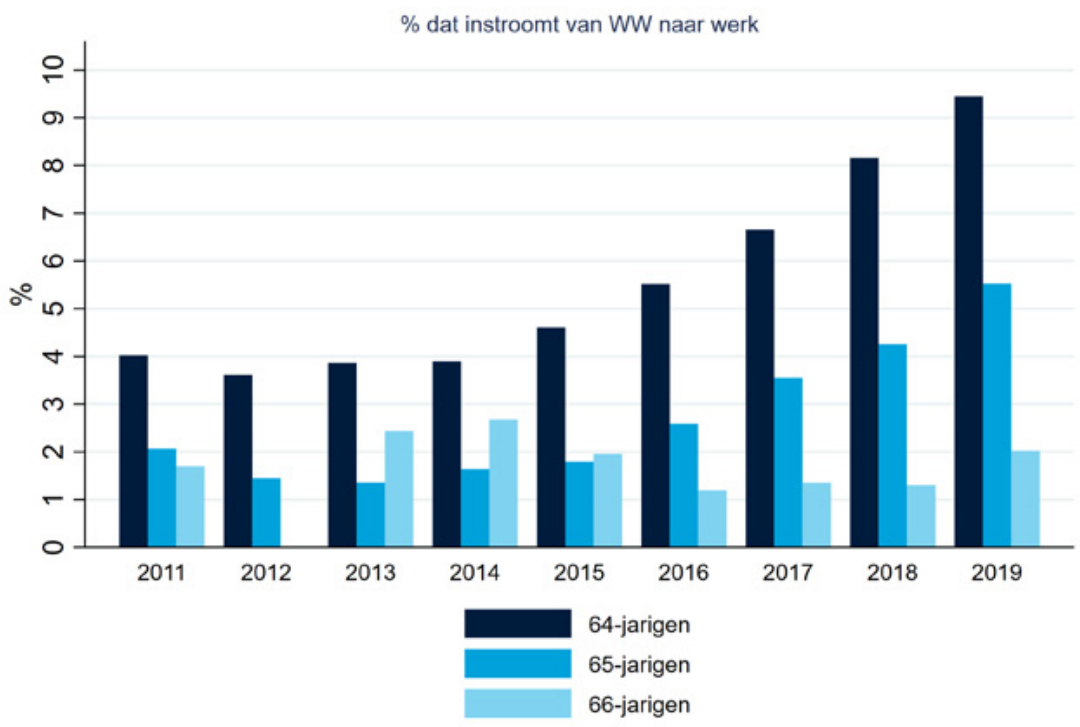

Bron: CBS Microdata. Bewerking door ROA

\subsection{Van WW naar werk}

De verhoging van de AOW-leeftijd vergroot niet alleen de kans dat mensen uitstromen naar de WW, WIA en ZW. Ook het omgekeerde is mogelijk. Het feit dat werkloze mensen langer op hun pensioen moeten wachten kan hen motiveren om meer te investeren in hun duurzame inzetbaarheid en om werk te gaan zoeken. Figuur 6 laat het percentage mensen zien die instromen van WW naar werk.

Uit de figuur blijkt dat het percentage mensen die instromen van WW naar werk vanaf 2014 fors is toegenomen voor 64-jarigen en 65-jarigen, terwijl voor 66-jarigen niet veel verandering is opgetreden. 9,3\% van de 64-jarigen in de WW keert terug naar werk. Soortgelijke trends van een toename van de instroom van WW naar werk zijn ook zichtbaar voor jongere leeftijdsgroepen, waardoor niet valt uit te sluiten dat deze trend grotendeels is toe te schrijven aan de conjunctuur. Wanneer echter gekeken wordt naar de trend voor ouderen naar opleidingsniveau (zie Appendix), is vooral een stevige stijging van WW naar werk zichtbaar voor laagopgeleiden. Hierbij speelt onder andere mee dat de groep hoogopgeleiden in de WW relatief klein is en derhalve selectie-effecten kunnen plaatsvinden. 


\subsection{Scholingsdeelname}

Om de inzetbaarheid van werknemers te vergroten en te voorkomen dat zij uitstromen naar een (arbeidsongeschiktheids)uitkering, kunnen werkgevers maatregelen treffen zoals het aanbieden van meer scholing. Werkgevers hebben hier belang bij, omdat het loon wordt doorbetaald en zij meebetalen aan de WIA. Daarnaast willen werkgevers het betalen van een ontslagvergoeding vermijden. De verhoging van de AOW-leeftijd zorgt er verder voor dat de periode waarin investeringen in menselijk kapitaal kunnen renderen langer is. Dit zou zowel werkgevers als werknemers moeten stimuleren om meer te investeren.

\section{Figuur 7}

Scholingsdeelname

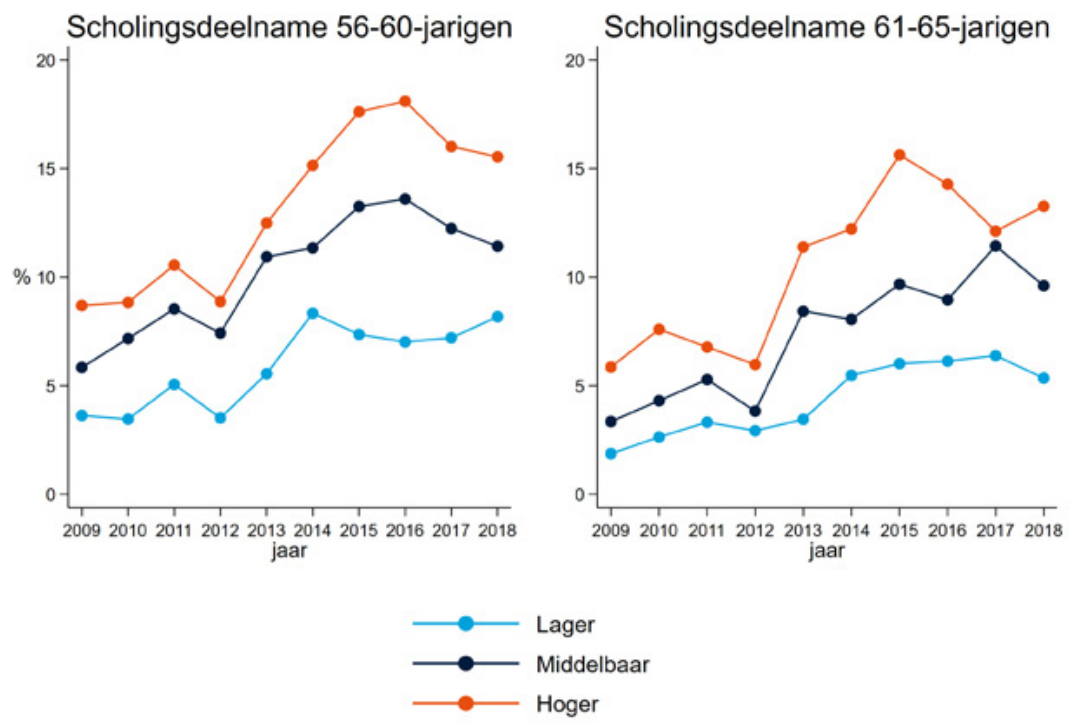

Bron: CBS Microdata. Bewerking door ROA

\section{Trends in de data}

De data over scholings-en cursusdeelname zijn beschikbaar tot en met 2018. Het aandeel werknemers dat scholing volgt is gedurende de periode 2009-2015 toegenomen. Met name vanaf 2012 loopt de stijging in het aandeel werknemers op dat een cursus volgt, met de grootste toename in scholing voor de leeftijdsklasse 56-60 jaar. Deze groep zag een toename van 6,8\% deelname aan een cursus in de afgelopen vier weken in 2012 naar $17 \%$ deelname in 2016. Zorgwekkend is dat de scholingsdeelname de laatste drie jaar is gedaald naar $12 \%$ in 2018. Dit is overigens niet alleen het geval voor oudere werknemers. Uit nadere analyses blijkt dat eenzelfde trend zichtbaar is voor de hele beroepsbevolking. 
Ook de stijging in de scholingsdeelname voor de leeftijdsklasse 61-65 jaar is aanzienlijk: gedurende de periode 2009-2015 stijgt de deelname van 4\% naar 9\%, een toename die bijna net zo groot is als voor de leeftijdsklasse 56-60 jaar. Echter, ook voor de groep is er een lichte kentering zichtbaar sinds 2016.

Als we kijken naar het verschil tussen opleidingsniveaus, dan valt op dat de laagopgeleiden minder deelnemen aan scholing en dat sinds 2012 dit verschil alleen maar groter is geworden, hoewel de kentering in scholingsdeelname sinds 2016 vooral hoogopgeleiden treft. Dit impliceert dus dat de inzetbaarheid van laagopgeleide ouderen mogelijkerwijs zal achterblijven.

\section{Figuur 8}

Cursusdeelname: door wie betaald?
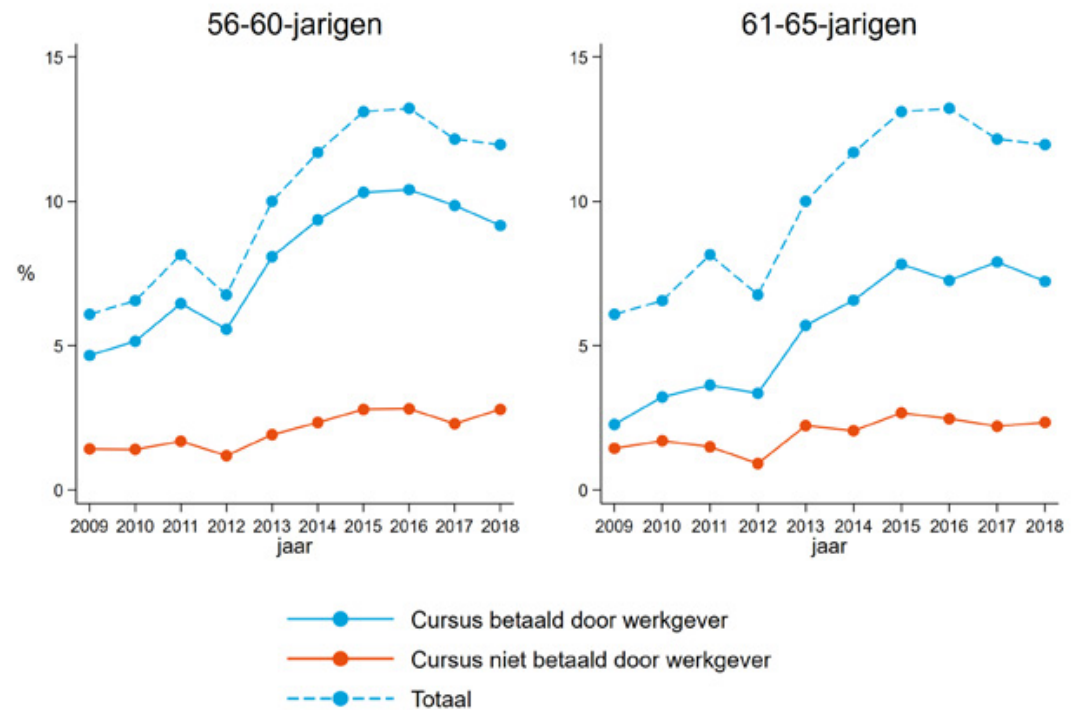

Bron: CBS Microdata. Bewerking door ROA

De vraag is vervolgens of de daling in de scholingsdeelname door werkgevers of werknemers wordt veroorzaakt. Figuur 8 geeft hierover uitkomst. De figuur laat zien wie voor de scholing betaalt. Duidelijk blijkt dat de daling in de scholingsdeelname vooral komt omdat cursussen betaald door de werkgever zijn gedaald. Het percentage cursussen die niet betaald worden door de werkgevers is zelfs licht toegenomen voor 56-60 jarigen en ongeveer gelijk gebleven voor de 61-65 jarigen. Echter, er moet ook worden opgemerkt dat de sterke stijging in de scholingsdeelname tot 2016 vooral door de werkgever werd geïnitieerd. Bovendien, de daling sinds 2016 in de scholingsdeelname die betaald werd door werkgevers was niet beperkt tot oudere werknemers. Eenzelfde daling was zichtbaar voor de hele beroepsbevoling. 


\subsection{Investeren in belastbaarheid}

Naar verwachting zullen werkgevers meer maatregelen treffen om taken te verlichten naarmate de AOW-leeftijd stijgt, met als doel de inzetbaarheid van werknemers te vergroten. Middelen hiervoor zijn bijvoorbeeld extra vrije dagen of het vrijstellen van ploegendiensten, en het verbeteren van de match tussen mogelijkheden en eisen. Anderzijds zal de langere periode dat mensen blijven doorwerken er ook toe kunnen leiden dat zij vaker nog promotie kunnen maken. Om te kijken naar de effectiviteit van de investeringen in de belastbaarheid, moet niet niet alleen naar initatieven worden gekeken zoals gerapporteerd door werkgevers. Veelal wordt HR-beleid gericht op duurzame inzetbaarheid ontwikkeld op CAO-niveau. De vraag is echter in welke mate werknemers toegang hebben tot dit beleid en ook op de hoogte zijn van de duurzame inzetbaarheidsinitiatieven binnen hun organisatie.

\section{Trends in de data}

Figuur 9 geeft een indirecte indicatie van hoe het HR-beleid gericht op de taakverlichting / uitbreiding zich heeft ontwikkeld over de jaren. Allereerst blijkt dat werknemers over de periode 2011-2019 iets vaker van functie zijn verwisseld. Hoewel functiewisselingen voor de 56-60-jarigen en 61-65-jarigen niet vaak voorkomen, zien we dat voor de eerste groep het percentage functiewisselingen is gestegen van $12,3 \%$ naar $14,2 \%$ en voor de laatste groep is gestegen van $9,1 \%$ naar $11,5 \%$. Een uitbreiding van de huidige functie in de afgelopen 2 jaar komt daarentegen relatief vaak voor. Opvallend is dat het percentage werknemers dat hiermee te maken krijgt ook licht gestegen is tussen 2011 en 2019. In 2011 rapporteerde 35,8\% van de 56-60-jarigen en $26,8 \%$ van 61-65-jarigen dat hun functie in de afgelopen 2 jaar was uitgebreid. In 2019 was dit respectievelijk 39,4\% en $31,7 \%$. Een taakuitbreiding duidt erop dat voor deze werknemers taakverlichting dus niet aan de orde was, hoewel niet met zekerheid gezegd kan worden hoe mensen de taakuitbreiding ervaren. In principe hoeft dit overigens niet problematisch te zijn als deze werknemers op dit moment geen problemen ervaren met hun werkbelasting en er ook een financïele compensatie tegenover de verzwaring van het takenpakket staat. Uit Figuur 9 blijkt verder dat het percentage werknemers dat promotie heeft gemaakt niet significant gestegen is. Dit geldt ook voor demotie.

Dat werkgevers bij hun HR-beleid gericht op functieveranderingen, promotie en demotie niet differentiëren tussen ouderen en jongeren blijkt uit nadere analyses waarin we deze variabelen ook geanalyseerd hebben voor de hele werkzame beroepsbevoling. Interessant is het percentage werknemers dat aangeeft te maken te hebben gehad met een taakuitbreiding, promotie of demotie nauwelijks afwijkt van die voor de 61- tot 65-jarigen. Ook zijn er geen verschillen in trends waarneembaar tussen de hele beroepsbevolking en oudere werknemers. 
Verder rapporteerden werknemers sinds 2011 een negatieve trend in hun kans om een nieuwe baan / functie te krijgen bij hun werkgever of bij andere werkgevers, waarschijnlijk als gevolg van de economische crisis (Figuur 10). Sinds 2016 zijn deze kansen weer substantieel toegenomen. Opvallend is dat 56-60 jarigen in 2019 hun kans op een nieuwe baan / functie bij een andere werkgever hoger inschatten dan bij hun huidige werkgever. Voor 61-65 jarigen geldt dat deze kans nog steeds hoger wordt ingeschat bij de huidige werkgever. Maar ook hier is het verschil in kansen kleiner geworden over de tijd. Terwijl 61-65-jarigen in 2011 hun kans 12,1\% kans hoger inschatten voor een nieuwe baan / functie bij hun huidige werkgever, was dit maar 7,1\% in 2019.

\section{Figuur 9}

Functieveranderingen

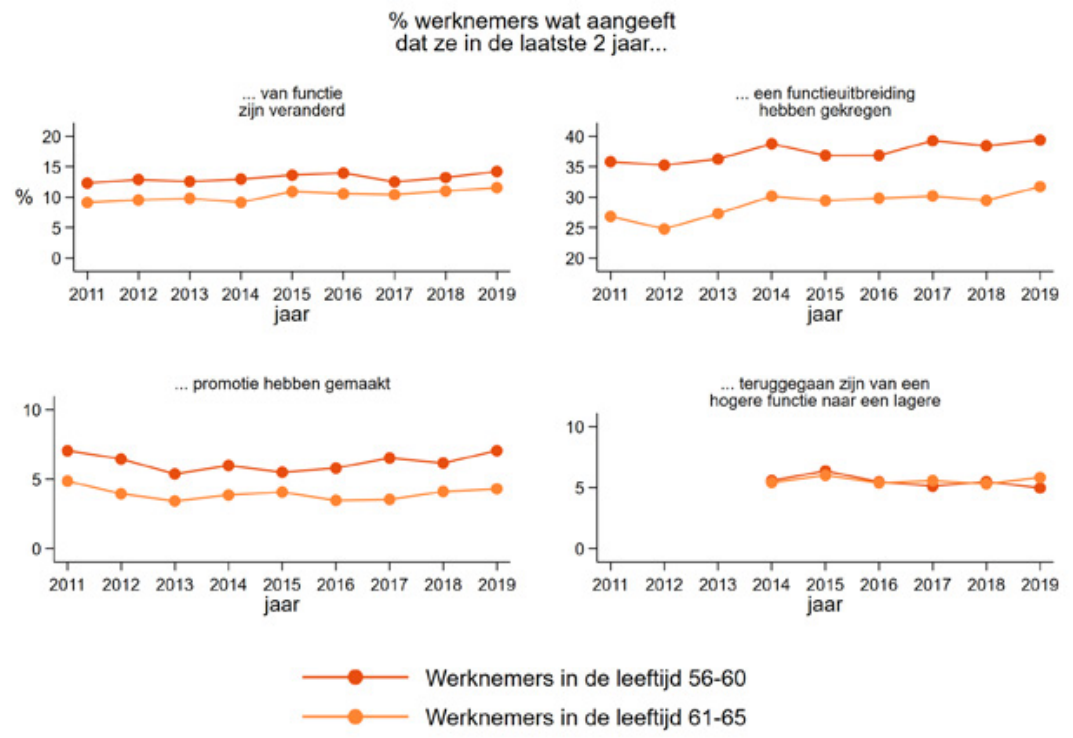

Bron: CBS Microdata. Bewerking door ROA 


\section{Figuur 10}

Kans op nieuwe baan / functie bij huidige of andere werkgever

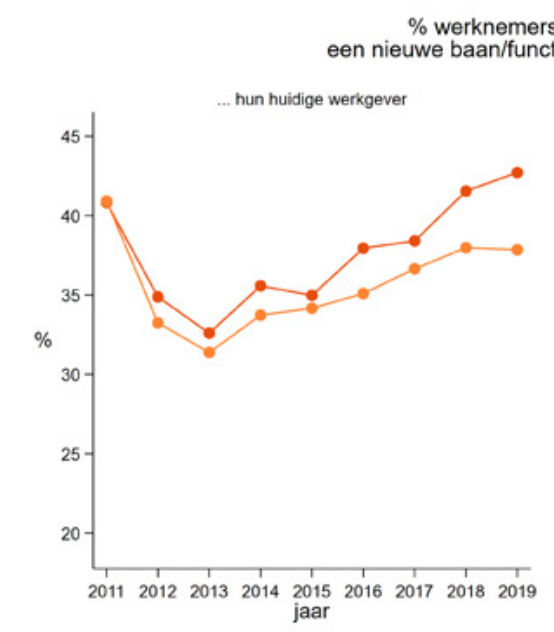
kunnen krijgen bij...
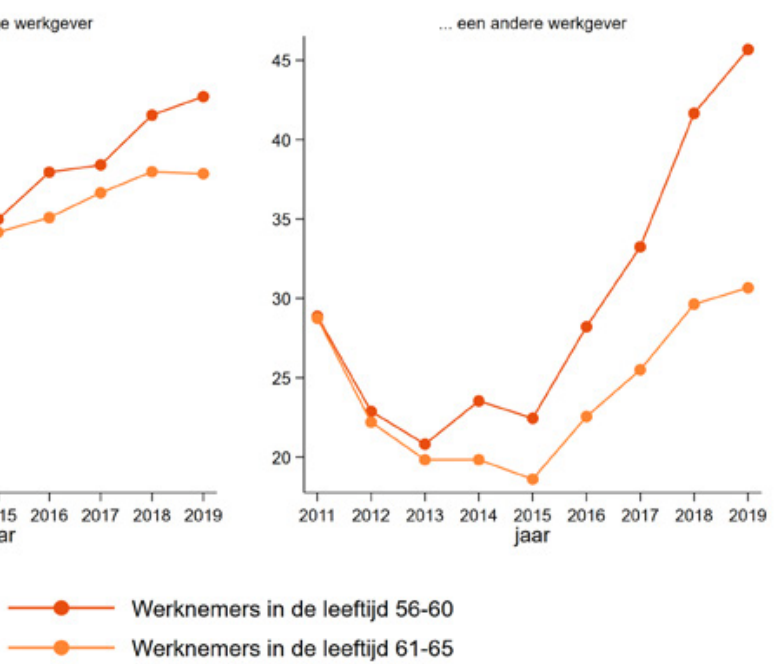

Bron: CBS Microdata. Bewerking door ROA 


\section{Uitkomsten voor werk, inkomen en gezondheid}

Het doel van de verhoging van de AOW-leeftijd is tweeledig: ten eerste moet de verhoging ervoor zorgen dat de arbeidsparticipatie hoger komt te liggen, en ten tweede zullen de AOW-lasten verlaagd worden vanwege de hogere arbeidsparticipatie. In het vorige hoofdstuk zijn de acties besproken die worden ondernomen door zowel werkgevers als werknemers om de inzetbaarheid en belastbaarheid van ouderen te vergroten, zodat de gestelde doelen van het verhogen van de AOW-leeftijd bereikt kunnen worden. Deze acties brengen echter ook neveneffecten met zich mee: zo wordt als gevolg van een latere gemiddelde uittreedleeftijd de kans verhoogd dat het beroep op arbeidsongeschiktheids- en werkloosheidsuitkeringen toeneemt. Daarnaast kunnen deze acties van invloed zijn op het inkomen, en zal de inzetbaarheid en algemene gezondheid van ouderen kunnen veranderen. Het vorige hoofdstuk liet reeds zien dat er sprake is van een kleine toename in de uitstroom naar de WW en de ZW / WIA.

In dit hoofdstuk worden de uitkomsten besproken voor de arbeidsmarkt: er wordt gekeken in hoeverre de verwachte uitkomsten zich hebben voorgedaan, en of hierin een trend valt te herkennen.

\subsection{Arbeidsmarkt en inkomen}

\section{Arbeidsparticipatie van ouderen neemt toe}

Door de financiële prikkel om door te werken werken veel ouderen langer door terwijl de uitstroom naar WW en WIA beperkt blijft. Daardoor kunnen we verwachten dat de arbeidsparticipatie toeneemt.

\section{Trends in de data}

Figuur 11 laat zien dat de arbeidsparticipatie van 65-jarigen fors is toegenomen sinds de verhoging van de AOW-leeftijd in 2012. Tegelijkertijd is het percentage mensen die AOW / pensioen als belangrijkste inkomstenbron hebben sterk gedaald voor deze groep. Met name vanaf 2013, als de AOW-leeftijd op 65 jaar komt te staan, zet de afname sterk door. Het percentage inkomen uit werk in de periode 2012-2019 is voor 65-jarigen gestegen van $6 \%$ naar $39 \%$. Voor 64 -jarigen is dit percentage gestegen van $21 \%$ naar $48 \%$. Deze grote toename in arbeidsparticipatie komt waarschijnlijk door de verhoging van de AOW-leeftijd. Zeker omdat uit Hoofdstuk 2 bleek dat de piekleeftijd om met pensioen te gaan steeds meer op de AOW-gerechtigde leeftijd ligt.

Voor 66-jarigen vinden dezelfde ontwikkelingen gematigder plaats gedurende deze periode, maar vanaf 2018 op 2019 zien we eveneens sterke veranderingen: het inkomen 
uit werk neemt toe van 10\% naar 19\%. Inkomen uit pensioen of AOW voor 66-jarigen daalt van 88\% naar 68\% tussen 2018 en 2019. Vooral het aandeel in loondienst neemt relatief sterk toe voor 66-jarigen. Het aandeel is tussen 2018 en 2019 drie keer zo groot geworden, van $4 \%$ naar $12 \%$, terwijl het aandeel zelfstandigen stijgt van $4 \%$ naar $5 \%$.

\section{Figuur 11}

Belangrijkste inkomstenbron
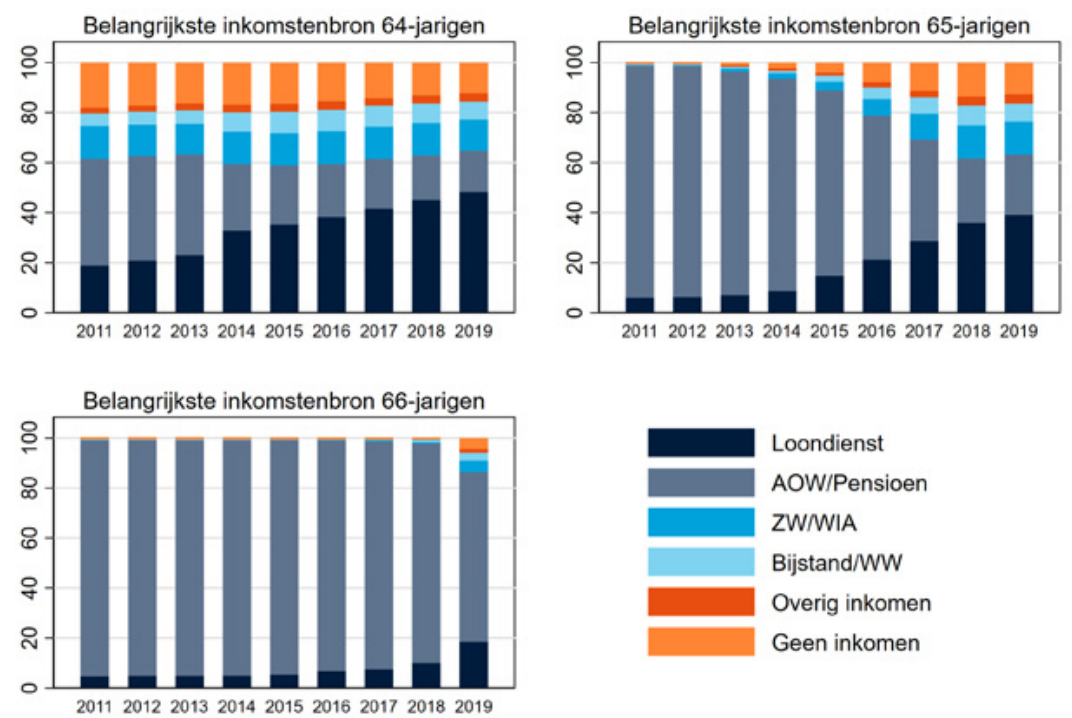

Bron: CBS Microdata. Bewerking door ROA

Tegelijkertijd zitten steeds meer ouderen in een uitkeringssituatie. Het aandeel 65-jarigen dat inkomen ontvangt uit bijstand, WW, ZW of WIA neemt geleidelijk toe tussen 2011 en 2017, en vanaf 2017 vlakt deze toename af (naar 13\% ZW en 7\% bijstand). Hetzelfde geldt voor het aandeel dat geen inkomen heeft. Voor 66-jarigen vinden deze toenames juist plaats vanaf 2018 als gevolg van dat de AOW-leeftijd dan op 66 jarige leeftijd ligt.

Het aandeel laagopgeleide 64-jarigen met een inkomen uit ZW/WIA of bijstand/WW is tussen 2011 en 2019 gestegen, van 22,5\% naar 27,5\% (met een piek van 29,5\% in 2016). Voor middelbaar opgeleiden blijft dit percentage gedurende deze periode echter hangen rond $17 \%$ en voor hoogopgeleiden rond de 12,5\%, waarbij beide groepen slechts een zeer lichte stijging zien. Voor 65-jarigen zijn deze verhoudingen in 2019 ongeveer hetzelfde. Het zijn dus duidelijk laagopgeleiden waarvoor uitkeringen (anders dan de AOW) een belangrijkere inkomensbron zijn geworden en dus problemen met hun inzetbaarheid ervaren.

\section{Effect op inkomen}

Het rendement van de AOW-leeftijd vertaalt zich niet alleen in de arbeidsparticipatie, maar ook in het inkomen dat ouderen verdienen. Of het inkomenseffect van het 
verhogen van de AOW-leeftijd positief of negatief is, hangt af van de stijging van de feitelijke uittreedleeftijd. Als deze minder snel stijgt dan de AOW-leeftijd, dan zal het inkomen van ouderen zowel voor als na de AOW-leeftijd dalen. Aangezien de pensioenleeftijd echter iets sneller stijgt zal het effect mogelijk positief zijn. Dit zou betekenen dat we een sterkere stijging zouden kunnen observeren voor degenen met een hogere AOW-leeftijd.

\section{Trends in de data}

Figuur 12 laat zien dat het bruto-inkomen vanaf 2009 onafgebroken is gestegen voor 64-, 65- en 66-jarigen. Deze stijging in het bruto-inkomen van 64-, 65- en 66-jarigen moet niet direct in verband gebracht worden met de verhoging van de AOW-leeftijd. Het inkomen van 66-jarigen volgt dezelfde stijgende trend als het inkomen van 64- en 65-jarigen, terwijl het inkomen van 66-jarigen voor het grootste deel van de gerapporteerde periode niet wordt beïnvloed door de stijging van de AOW-leeftijd. Vermoedelijk hangt dit samen met de economische groei en cohort-effecten. Kijkend naar de verschillen in inkomens tussen de drie leeftijdsgroepen door de jaren heen laat wel zien dat het inkomensverschil tussen de groepen langzaam groter wordt. Dit kan duiden op een causaal effect van de verhoging van de AOW-leeftijd. De verhoging van de gemiddelde pensioenleeftijd zorgt ervoor dat werknemers langer doorwerken en derhalve een hoger inkomen hebben. De vervangingsratio van een doorsnee huishouden na pensionering is daarentegen 86 procent van het bruto-inkomen dat het huishouden verdiende voor pensionering (Knoef et al. 2017). Dat er sprake kan zijn van een causaal effect blijkt ook uit dat het verschil tussen 64- en 65-jarigen vooral na 2015 weer kleiner werd. Rond deze tijd acceleerde de stijging in de AOW-leeftijd. Bovendien is er sprake van een relatief sterke stijging onder 66-jarigen tussen 2018 en 2019, het moment dat de AOW-leeftijd en de piekleeftijd in de gemiddelde pensioenleeftijd 66 jaar is. Het inkomensverschil tussen 64-jarigen en 66-jarigen neemt af van van 6799 euro verschil naar 5788 euro verschil. Het is echter te voorbarig om dit met zekerheid te kunnen stellen. Gedurende de komende jaren zal duidelijker worden of dit verschil verder afneemt, als de AOW-leeftijd voor meerdere jaren op rij hoger ligt dan 66 jaar.

Relevant is ook om op te merken dat het bruto-inkomen van de hele beroepsbevolking gemiddeld genomen minder sterk is gestegen dan die voor 64-, 65-, en 66-jarigen: het inkomen nam toe van ongeveer 34,500 euro in 2009 naar 38,000 euro in 2019.

Figuur 13 toont de trends in het bruto-inkomen naar opleidingsniveau. Met behulp van deze uitsplitsing wordt het duidelijker waar de oorsprong van de uitwaaiering van inkomens tussen de leeftijden vandaan komt. In 2019 verdient een 66-jarige hoogopgeleide ongeveer $€ 8000$ minder dan een 64 -jarige. Dit verschil bedraagt ongeveer $€ 4000$ voor middelbaar opgeleiden en $€ 2000$ voor laagopgeleiden. In 2009 waren deze verschillen veel kleiner voor laagopgeleiden en middelbaar opgeleiden. Bij hoogopgeleiden blijft dit verschil ongeveer gelijk. De uitwaaiering is het sterkst voor de middelbaar opgeleiden. Dit laatste is consistent met wat we zouden verwachten met een causaal effect van de AOW-leeftijd en de andere hervormingen van het pensioenstelsel. De pensioenannu- 
iteit van een laagopgeleid huishouden is immers doorgaans hoger in percentage van het bruto salaris dan van een middelbaar- of hoogopgeleid huishouden. Tegelijkertijd hebben hoogopgeleide huishoudens doorgaans meer eigen vermogen om pensioenhervormingen te compenseren. Het langer doorwerken zal dus vooral het inkomen van middelbaar opgeleiden positief moeten beïnvloeden.

\section{Figuur 12}

Ontwikkeling Bruto-inkomen

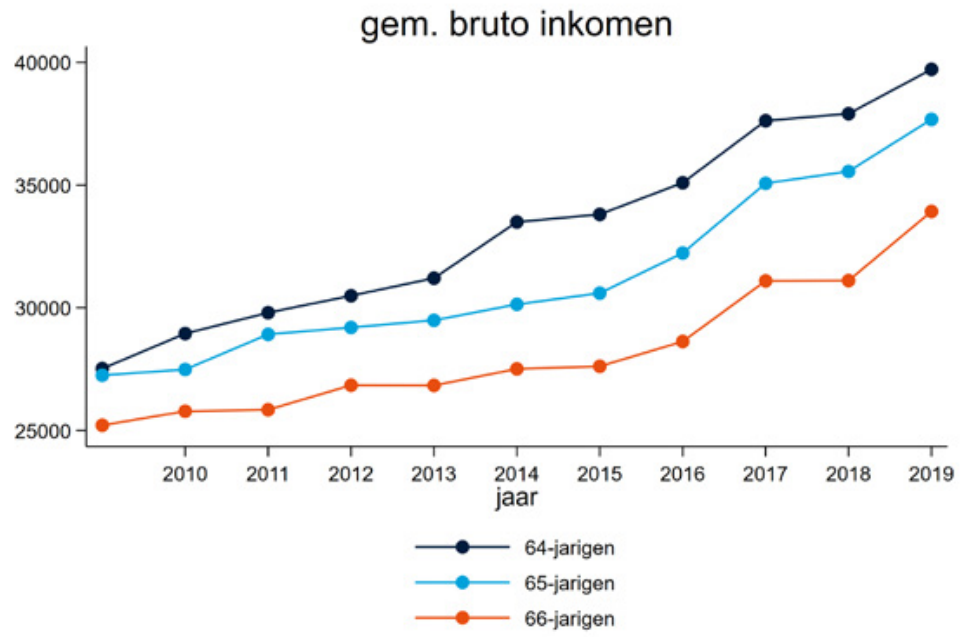

Bron: CBS Microdata. Bewerking door ROA 


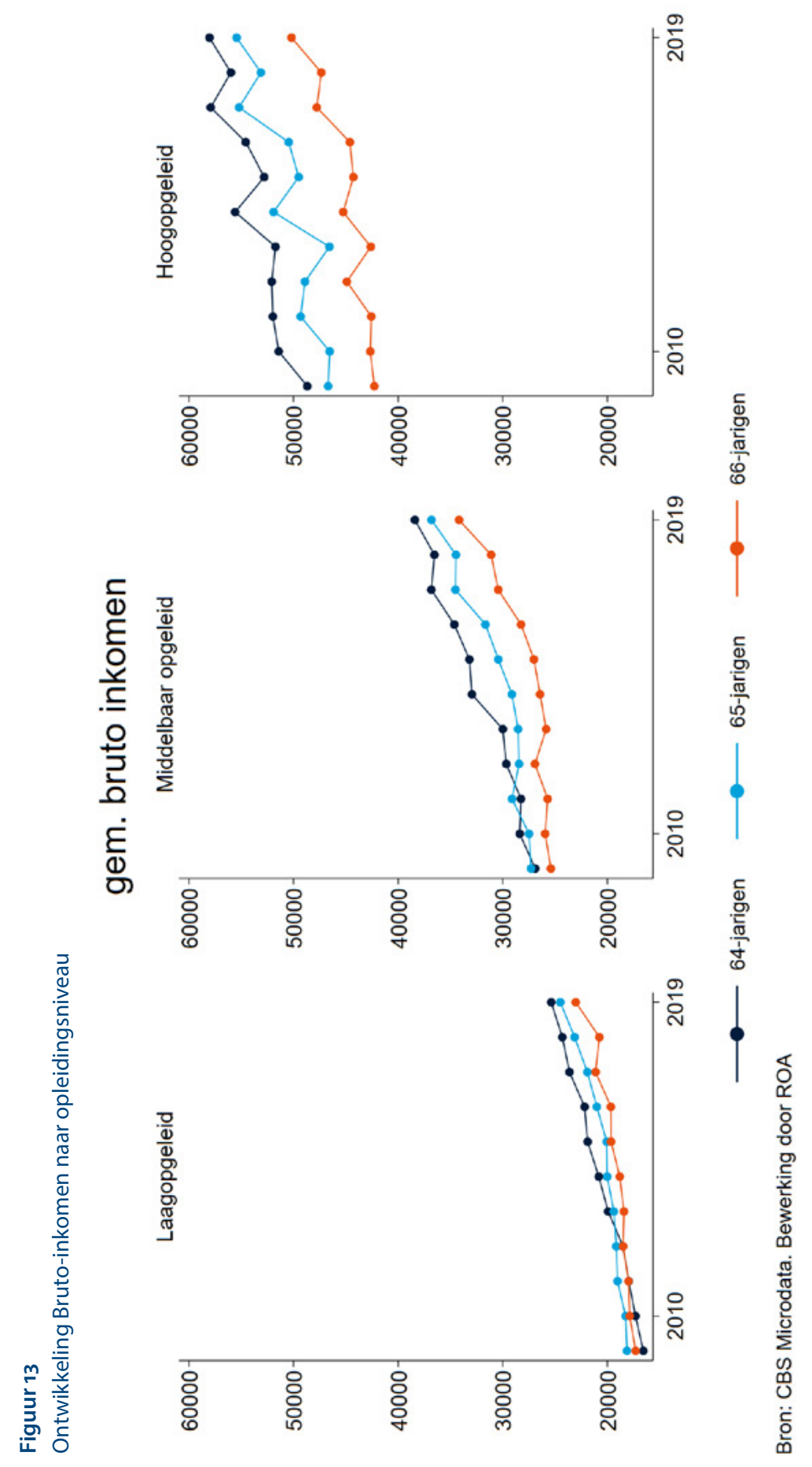




\subsection{Inzetbaarheid en gezondheid}

De verwachting is dat inspanningen van werkgevers en werknemers om de inzetbaarheid te verhogen ervoor zal zorgen dat de inzetbaarheid van oudere werknemers zal stijgen.

\section{Trends in de data}

Figuur 14 toont het percentage werknemers en zelfstandigen van 56-60 jaar en 61-65 jaar dat aangeeft te kunnen voldoen aan de fysieke en psychische eisen van het werk. Voor werknemers is voor wat betreft fysieke eisen geen patroon te herkennen door de jaren heen: voor de leeftijdsklasse 56-60 jaar denkt ongeveer $84 \%$ te kunnen voldoen aan de fysieke eisen, voor de leeftijdsklasse $61-65$ jaar is dat ongeveer $81 \%$. Als we dit uitsplitsen naar opleidingsniveau, is te zien dat laagopgeleiden minder vaak voldoen aan fysieke eisen vergeleken met hoogopgeleiden en dat laagopgeleiden langzaam steeds minder voldoen aan deze fysieke eisen ( $78,9 \%$ in $2012,76,5 \%$ in 2019$)$.

\section{Figuur 14}

Kunnen voldoen aan fysieke en psychische eisen

$\%$ werknemers dat makkelijk kan voldoen aan...
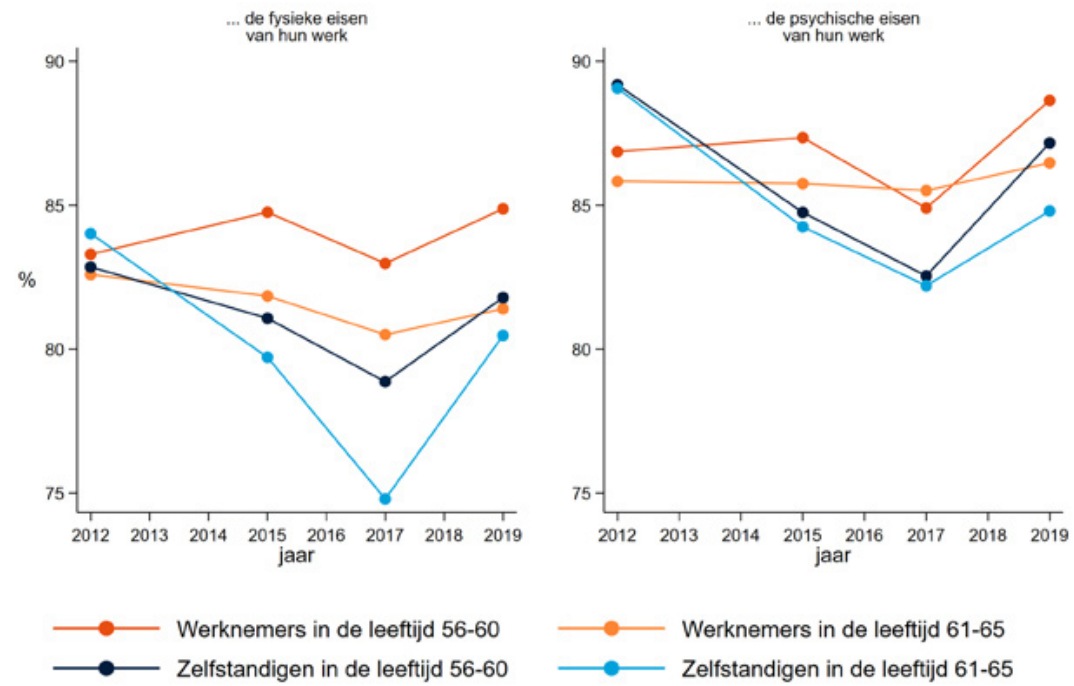

Bron: CBS Microdata. Bewerking door ROA

Voor het voldoen aan psychische eisen is ook geen duidelijk patroon zichtbaar voor de werknemers (88\% voor 56-60 jaar, 86\% voor 61-65 jaar in 2019), afgezien dat laagopgeleiden iets beter voldoen aan psychische eisen vergeleken met hoogopgeleiden.

Voor zelfstandigen was een negatieve trend zichtbaar tot 2017 voor zowel de fysieke als psychische eisen. Vanaf 2017 is er weer sprake van herstel. Het is onwaarschijnlijk dat 
deze dalingen te maken hebben met de verhoging van de AOW-leeftijd, het effect kan ook samenhangen met een verandering in de samenstelling van de groep zelfstandigen als gevolg van de toename in het aantal zzp'ers. Bovendien hebben zelfstandigen veel meer flexibiliteit in hun keuze om met pensioen te gaan doordat zij niet geconfronteerd worden met functioneel leeftijdsontslag. In tegenstelling tot werknemers kunnen zij vaker doorwerken na de AOW-leeftijd.

Tot slot, een belangrijke indicator voor de inzetbaarheid is de ervaren gezondheid. Figuur 15 toont de trends in de ervaren gezondheid van 64-, 65- en 66-jarigen. Het blijkt uit de figuur dat de ervaren gezondheid tussen 2010 en 2019 nauwelijks is veranderd. Het percentage dat een goede tot zeer goede gezondheid ervaart schommelt in de periode 2010-2019 voor 64-jarigen en 65-jarigen steeds tussen de $60 \%$ en $80 \%$, zonder dat hier een duidelijk patroon in te herkennen is. Hiermee verschillen ouderen niet van de hele beroepsbevolking waarvoor we eveneens geen significante trends observeren.

\section{Figuur 15}

Ervaren gezondheid

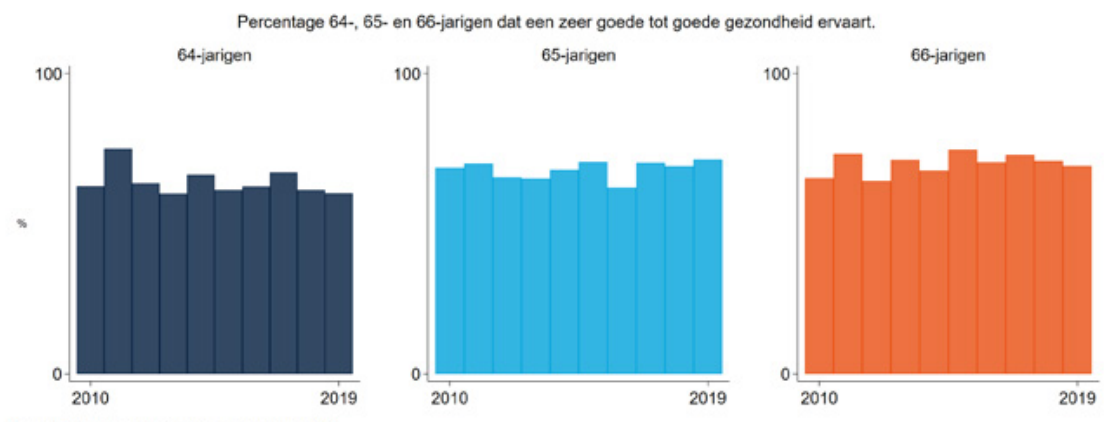

Bron: CBS Microdata. Bewerking door ROA

Als echter gekeken wordt naar ervaren gezondheid per opleidingsniveau, treden er duidelijke verschillen op. Vooral voor laagopgeleiden laat het percentage goede/zeer goede ervaren gezondheid een neerwaartse trend zien voor zowel 56-60 als 61-65 jarigen (Figuur 16). Wat betreft hoogopgeleiden ligt de ervaren gezondheid structureel hoger dan voor middelbaar- en laagopgeleiden, maar ook hier is geen duidelijke trend herkenbaar. Het is dus mogelijk dat de verschillen in de komende jaren steeds groter worden tussen opleidingsniveaus. Het is van belang om deze verschillen ook in de toekomst te blijven monitoren.

Het gebrek aan significante trends in de gemiddelde ervaren gezondheid komt eveneens tot uiting in de trend van de gemiddelde levensverwachting (Figuur 17). In Nederland is sprake van een lichte toename van de gezonde levensverwachting van 65-jarigen sinds de stijging van de AOW-leeftijd (in mindere mate voor mannen vergeleken met vrouwen als gevolg van verbeteringen in de gezondheidszorg en gezonde leefstijl). Echter, er zijn geen significante verschillen te onderscheiden op het moment dat de AOW-leeftijd is verhoogd. 
Figuur 16

Ervaren gezondheid naar opleidingsniveau
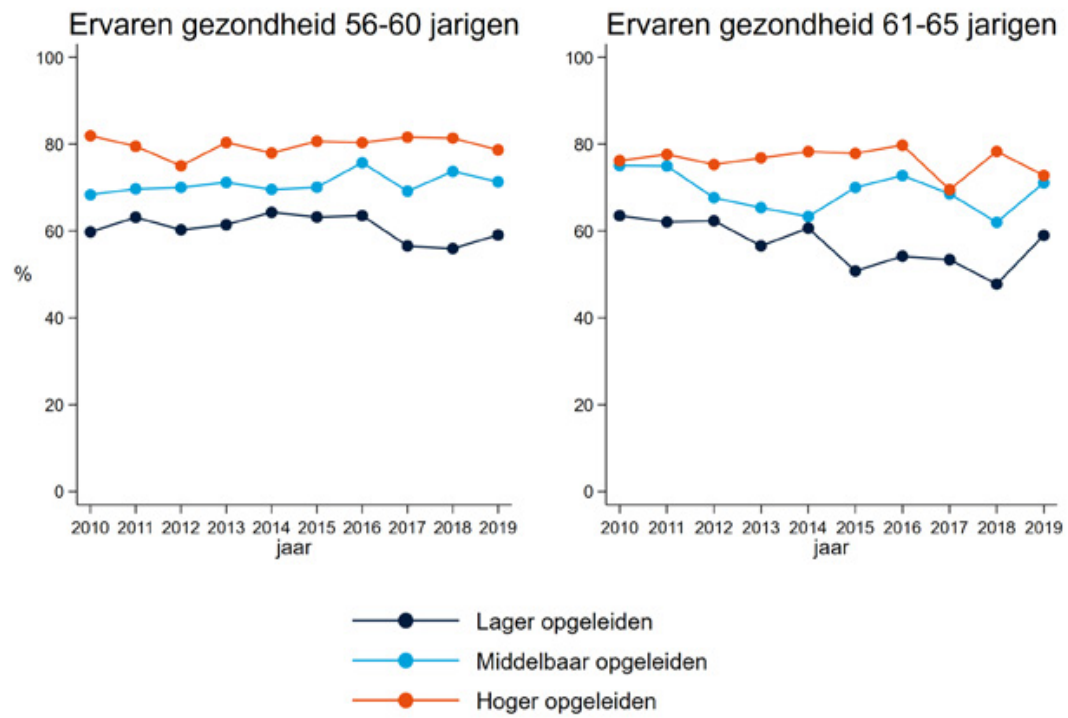

Bron: CBS Microdata. Bewerking door ROA

\section{Figuur 17}

Ervaren gezondheid naar opleidingsniveau

Levensverwachting in...

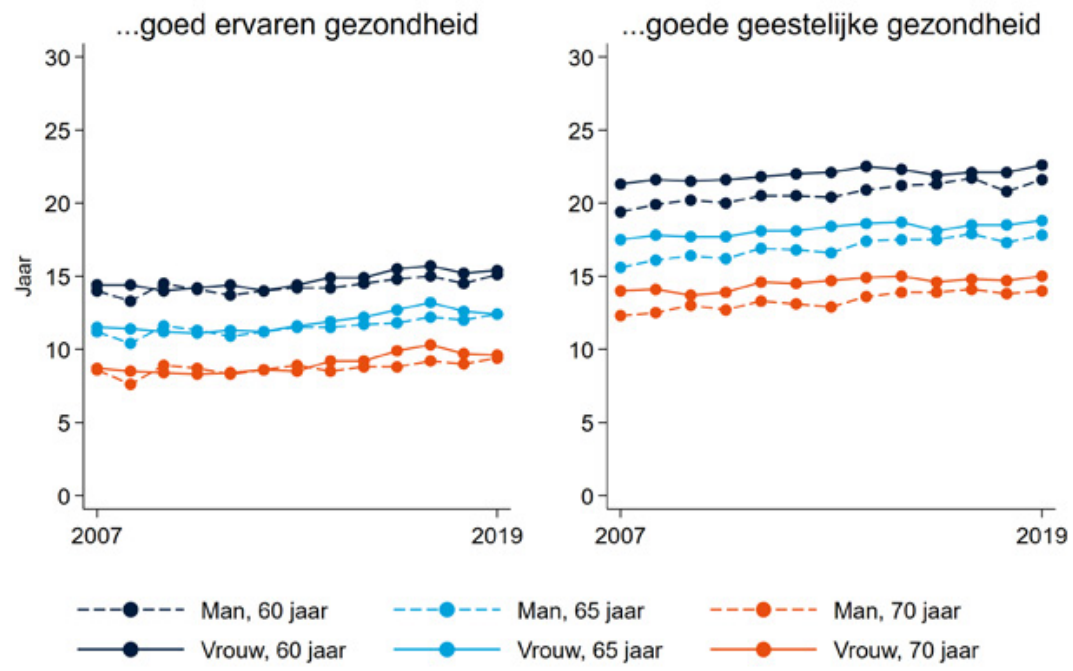

Bron: CBS Microdata. Bewerking door ROA 


\section{Literatuur}

\section{Literatuuropsomming rapport}

Ministerie van Sociale Zaken en Werkgelegenheid/SEO. Effect verhoging AOW-leeftijd. Resultaten monitor-en literatuuronderzoek-Rapport-Kennisplatform Werk en Inkomen. 2020.

Berendsen, E., en Rijnsburger, P. (2021) Volumeontwikkelingen voorjaar 2021, UWVKennisverslag 2021-4, Amsterdam.

\section{Literatuuropsomming artikel in tijdschrift}

Blau, D., \& Goodstein, R. M. (2010). Can Social Security Explain Trends in Labor Force Participation of Older Men in the United States? Journal of Human Resources, 45(2), 328-363.

Borsch-Supan, A. (2000). A Model Under Siege: A Case Study of the German Retirement Insurance System. The Economic Journal, 110(461), F24-F45.

Coile, C., \& Gruber, J. (2007). Future Social Security Entitlements and the Retirement Decision. The Review of Economics and Statistics, 89(2), 234-246.

De Grip, A., Fouarge, D., \& Montizaan, R. (2013). How Sensitive are Individual Retirement Expectations to Raising the Retirement Age? De Economist, 161(3), 225-251.

De Grip, A., Lindeboom, M., \& Montizaan, R. (2012). Shattered Dreams: The Effects of Changing the Pension System Late In the Game. The Economic Journal, 122(559), 1-25.

Fetter, D. K., \& Lockwood, L.M. (2018). Government Old-Age Support and Labor Supply: Evidence from the Old Age Assistance Program. American Economic Review, 108(8), 2174-2211.

Knoef, M., Been, J., Caminada, K., Goudswaard, K., \& Rhuggenaath, J. (2017). De toereikendheid van pensioenopbouw na de crisis en pensioenhervormingen. Netspar Design Paper, 68.

Krueger, A. B., \& Pischke, J. (1992). The Effect of Social Security on Labor Supply: A Cohort Analysis of the Notch Generation. Journal of Labor Economics, 10(4), 412-437.

Lalive, R., \& Staubli, S. (2014). How does raising women's full retirement age affect labor supply, income, and mortality? Evidence from Switzerland. In Joint Meeting of the Retirement Research Consortium Conference Volume.

Lindeboom, M., \& Montizaan, R. (2020). Disentangling retirement and savings responses. Journal of Public Economics, 192(December 2020).

Montizaan, R. M., de Grip, A., Cörvers, F., \& Dohmen, T. J. (2016). The impact of negatively reciprocal inclinations on worker behavior: Evidence from a retrenchment of pension rights. Management Science, 62(3), 668-681.

Montizaan, R. M., \& Vendrik, M. C. M. (2014). Misery loves company: exogenous shocks in retirement expectations and social comparison effects on subjective well-being. Journal of Economic Behavior \& Organization, 97, 1-26.

Staubli, S., \& Zweimüller, J. (2013). Does raising the early retirement age increase employment of older workers? Journal of public economics, 108, 17-32.

Mastrobuoni, 2009; Gelber et al., 2016 



\section{Appendix A: Cijfers Figuren}

\section{Figuur A1}

Gemiddelde pensioenleeftijd naar inkomensklasse

\section{Gemiddelde pensioenleeftijd}
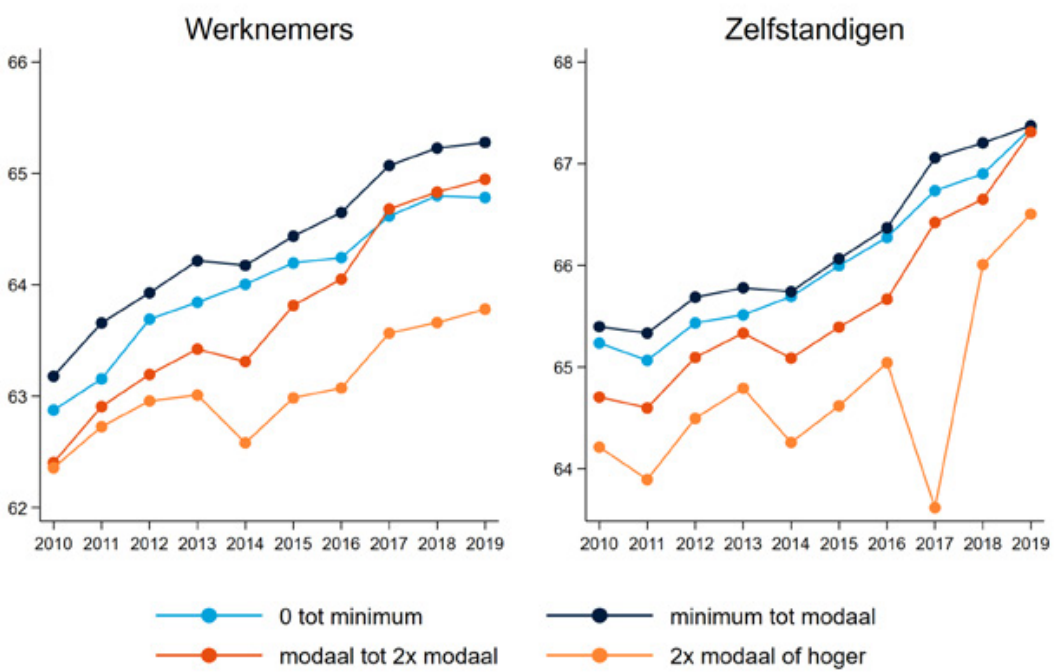

Bron: CBS Microdata. Bewerking door ROA 
Tabel A1.1

Leeftijd tot welke mensen willen en denken te kunnen werken

\begin{tabular}{|c|c|c|c|c|}
\hline Jaar & 2012 & 2015 & 2017 & 2019 \\
\hline \multicolumn{5}{|c|}{ Gemiddelde leeftijd tot welke mensen willen werken } \\
\hline \multicolumn{5}{|l|}{ Werknemers } \\
\hline Leeftijdsklasse 56-60 & 64,1 & 64,7 & 64,6 & 64,5 \\
\hline Leeftijdsklasse 61-65 & 65,1 & 65,6 & 65,8 & 65,7 \\
\hline \multicolumn{5}{|l|}{ Zelfstandigen } \\
\hline Leeftijdsklasse 56-60 & 66,5 & 66,4 & 66,3 & 66,9 \\
\hline Leeftijdsklasse 61-65 & 69,4 & 68,5 & 67,9 & 67,6 \\
\hline \multicolumn{5}{|c|}{ Gemiddelde leeftijd waar tot mensen in staat zijn om te werken } \\
\hline \multicolumn{5}{|l|}{ Werknemers } \\
\hline Leeftijdsklasse 56-60 & 64,5 & 65,1 & 64,8 & 64,7 \\
\hline Leeftijdsklasse $61-65$ & 66,1 & 66,3 & 66,2 & 66,1 \\
\hline \multicolumn{5}{|l|}{ Zelfstandigen } \\
\hline Leeftijdsklasse 56-60 & 67,6 & 67,6 & 67,0 & 68,2 \\
\hline Leeftijdsklasse 61-65 & 70,2 & 69,8 & 69,2 & 69,0 \\
\hline
\end{tabular}

Bron: CBS Microdata (NEA). Bewerking door ROA 


\section{Tabel A1.2}

Leeftijd tot welke mensen willen en denken te kunnen werken, naar opleiding

\begin{tabular}{|c|c|c|c|c|c|}
\hline Jaar & & 2012 & 2015 & 2017 & 2019 \\
\hline \multicolumn{6}{|c|}{ Gemiddelde leeftijd tot welke mensen willen werken } \\
\hline \multicolumn{6}{|l|}{ Werknemers } \\
\hline Laagopgeleid & Leeftijdsklasse 56-60 & 64,0 & 64,7 & 64,5 & 64,6 \\
\hline Laagopgeleid & Leeftijdsklasse $61-65$ & 65,0 & 65,7 & 65,8 & 65,7 \\
\hline Middelbaar opgeleid & Leeftijdsklasse 56-60 & 63,9 & 64,6 & 64,5 & 64,3 \\
\hline Middelbaar opgeleid & Leeftijdsklasse $61-65$ & 65,2 & 65,5 & 65,8 & 65,6 \\
\hline Hoogopgeleid & Leeftijdsklasse 56-60 & 64,3 & 64,9 & 64,8 & 64,6 \\
\hline Hoogopgeleid & Leeftijdsklasse $61-65$ & 65,2 & 65,7 & 65,9 & 65,8 \\
\hline \multicolumn{6}{|l|}{ Zelfstandigen } \\
\hline Laagopgeleid & Leeftijdsklasse 56-60 & 64,5 & 67,0 & 65,4 & 66,4 \\
\hline Laagopgeleid & Leeftijdsklasse 61-65 & 68,2 & 68,0 & 66,6 & 66,7 \\
\hline Middelbaar opgeleid & Leeftijdsklasse 56-60 & 66,6 & 65,8 & 65,8 & 66,4 \\
\hline Middelbaar opgeleid & Leeftijdsklasse $61-65$ & 69,8 & 68,3 & 67,6 & 67,2 \\
\hline Hoogopgeleid & Leeftijdsklasse 56-60 & 67,4 & 66,7 & 67,2 & 67,3 \\
\hline Hoogopgeleid & Leeftijdsklasse 61-65 & 69,7 & 68,8 & 68,7 & 68,4 \\
\hline \multicolumn{6}{|c|}{ Gemiddelde leeftijd waar tot mensen in staat zijn om te werken } \\
\hline \multicolumn{6}{|l|}{ Werknemers } \\
\hline Laagopgeleid & Leeftijdsklasse 56-60 & 64,0 & 64,7 & 64,0 & 64,0 \\
\hline Laagopgeleid & Leeftijdsklasse 61-65 & 65,6 & 66,1 & 65,9 & 65,6 \\
\hline Middelbaar opgeleid & Leeftijdsklasse 56-60 & 64,2 & 64,8 & 64,5 & 64,4 \\
\hline Middelbaar opgeleid & Leeftijdsklasse 61-65 & 66,1 & 66,1 & 66,0 & 66,1 \\
\hline Hoogopgeleid & Leeftijdsklasse 56-60 & 65,2 & 65,8 & 65,8 & 65,7 \\
\hline Hoogopgeleid & Leeftijdsklasse 61-65 & 66,7 & 66,7 & 66,7 & 66,6 \\
\hline \multicolumn{6}{|l|}{ Zelfstandigen } \\
\hline Laagopgeleid & Leeftijdsklasse 56-60 & 65,6 & 68,1 & 66,2 & 67,3 \\
\hline Laagopgeleid & Leeftijdsklasse $61-65$ & 69,5 & 68,5 & 67,8 & 66,3 \\
\hline Middelbaar opgeleid & Leeftijdsklasse 56-60 & 67,5 & 66,3 & 66,6 & 67,1 \\
\hline Middelbaar opgeleid & Leeftijdsklasse $61-65$ & 69,6 & 68,6 & 68,5 & 68,8 \\
\hline Hoogopgeleid & Leeftijdsklasse 56-60 & 68,5 & 68,5 & 67,7 & 69,0 \\
\hline Hoogopgeleid & Leeftijdsklasse $61-65$ & 71,1 & 71,3 & 70,3 & 70,4 \\
\hline
\end{tabular}

Bron: CBS Microdata (NEA). Bewerking door ROA 
Tabel A2

Gemiddelde pensioenleeftijd

\begin{tabular}{|c|c|c|c|c|c|c|c|c|c|c|}
\hline Jaar & 2010 & 2011 & 2012 & 2013 & 2014 & 2015 & 2016 & 2017 & 2018 & 2019 \\
\hline $\begin{array}{l}\text { Gemiddelde pensioenleeftijd } \\
\text { zelfstandigen }\end{array}$ & 65,0 & 64,9 & 65,3 & 65,4 & 65,4 & 65,7 & 66,0 & 66,0 & 66,8 & 67,3 \\
\hline $\begin{array}{l}\text { Gemiddelde pensioenleeftijd } \\
\text { werknemers }\end{array}$ & 62,6 & 63,1 & 63,4 & 63,6 & 63,5 & 63,9 & 64,0 & 64,5 & 64,7 & 64,7 \\
\hline
\end{tabular}

Tabel A3.1

Stromen van werk naar WW/bijstand en WIA/ZW (\%)

\begin{tabular}{|c|c|c|c|c|c|c|c|c|c|}
\hline Jaar & 2011 & 2012 & 2013 & 2014 & 2015 & 2016 & 2017 & 2018 & 2019 \\
\hline \multicolumn{10}{|c|}{ Van werk naar WW/bijstand } \\
\hline 56-60 jarigen & 2,1 & 2,8 & 3,3 & 2,8 & 2,7 & 2,2 & 1,6 & 1,3 & 1,3 \\
\hline 64 jaar & 2,0 & 2,5 & 2,9 & 3,5 & 4,0 & 3,3 & 2,6 & 2,1 & 1,9 \\
\hline 65 jaar & 0,0 & 0,1 & 1,9 & 2,0 & 3,6 & 3,3 & 2,7 & 2,6 & 2,4 \\
\hline 66 jaar & 0,0 & 0,1 & 0,0 & 0,0 & 0,0 & 0,0 & 0,1 & 0,2 & 1,4 \\
\hline \multicolumn{10}{|c|}{ Van werk naar WIA/ZW } \\
\hline 56-60 jarigen & 1,1 & 1,0 & 1,0 & 0,9 & 0,9 & 0,9 & 0,9 & 0,9 & 0,9 \\
\hline 64 jaar & 1,1 & 1,0 & 1,0 & 1,0 & 1,1 & 1,2 & 1,3 & 1,3 & 1,3 \\
\hline 65 jaar & 0,0 & 0,0 & 1,1 & 1,1 & 0,9 & 1,2 & 1,1 & 1,3 & 1,3 \\
\hline 66 jaar & 0,0 & 0,0 & 0,0 & 0,0 & 0,0 & 0,0 & 0,0 & 0,1 & 0,6 \\
\hline
\end{tabular}

Bron: CBS Microdata. Bewerking door ROA

\section{Tabel A3.2}

Stromen van WW naar werk (\%)

\begin{tabular}{|l|r|r|r|r|r|r|r|r|r|}
\hline Jaar & 2011 & 2012 & 2013 & 2014 & 2015 & 2016 & 2017 & 2018 & 2019 \\
\hline $56-60$ jarigen & 21,6 & 20,1 & 17,9 & 20,2 & 24,3 & 27,3 & 31,7 & 35,1 & 38,6 \\
\hline 64 jaar & 4,0 & 3,6 & 3,9 & 3,9 & 4,6 & 5,5 & 6,7 & 8,2 & 9,4 \\
\hline 65 jaar & 2,1 & 1,4 & 1,4 & 1,6 & 1,8 & 2,6 & 3,6 & 4,3 & 5,5 \\
\hline 66 jaar & 1,7 & 0,0 & 2,4 & 2,7 & 2,0 & 1,2 & 1,4 & 1,3 & 2,0 \\
\hline
\end{tabular}

Bron: CBS Microdata. Bewerking door ROA 


\section{Tabel A3.3}

Stroom van WW naar werk, naar opleiding (\%)

\begin{tabular}{|c|c|c|c|c|c|c|c|c|c|}
\hline Jaar & 2011 & 2012 & 2013 & 2014 & 2015 & 2016 & 2017 & 2018 & 2019 \\
\hline \multicolumn{10}{|l|}{ 55-60 jaar } \\
\hline Laagopgeleid & 18,6 & 16,6 & 13,9 & 16,1 & 19,7 & 22,0 & 27,5 & 30,8 & 35,5 \\
\hline Middelbaar opgeleid & 24,3 & 21,3 & 19,1 & 21,3 & 26,1 & 29,0 & 33,4 & 37,4 & 40,3 \\
\hline Hoogopgeleid & 23,7 & 22,9 & 21,3 & 23,6 & 26,8 & 30,3 & 33,4 & 36,6 & 39,9 \\
\hline Onbekend & 20,2 & 20,2 & 4,9 & 5,5 & 8,9 & 11,4 & 24,0 & 19,9 & 28,3 \\
\hline \multicolumn{10}{|l|}{64 jaar } \\
\hline Laagopgeleid & 3,4 & 3,0 & 3,2 & 3,1 & 3,7 & 4,3 & 6,3 & 7,5 & 10,2 \\
\hline Middelbaar opgeleid & 3,4 & 3,6 & 4,0 & 4,2 & 5,0 & 6,4 & 7,6 & 9,4 & 10,9 \\
\hline Hoogopgeleid & 8,0 & 4,3 & 5,9 & 4,4 & 5,8 & 5,9 & 6,4 & 8,2 & 8,9 \\
\hline Onbekend & 3,5 & 3,8 & 1,3 & 4,7 & 1,9 & 2,7 & 2,1 & 2,6 & 3,1 \\
\hline \multicolumn{10}{|l|}{65 jaar } \\
\hline Laagopgeleid & 0,9 & 0,8 & 0,9 & 1,3 & 1,5 & 1,8 & 2,9 & 3,6 & 5,4 \\
\hline Middelbaar opgeleid & 2,6 & 2,0 & 1,8 & 1,5 & 1,8 & 2,9 & 3,9 & 5,1 & 6,5 \\
\hline Hoogopgeleid & 4,2 & 2,2 & 1,6 & 2,2 & 2,2 & 3,2 & 3,9 & 4,3 & 5,5 \\
\hline Onbekend & 1,9 & 1,2 & 1,1 & 2,2 & 1,5 & 2,1 & 2,4 & 2,0 & 2,0 \\
\hline \multicolumn{10}{|l|}{66 jaar } \\
\hline Laagopgeleid & $x$ & $x$ & 3,2 & 2,5 & 2,3 & 1,2 & 1,1 & 1,6 & 2,2 \\
\hline Middelbaar opgeleid & $x$ & $x$ & 8,0 & 3,8 & 1,2 & 1,0 & 1,5 & 1,4 & 2,2 \\
\hline Hoogopgeleid & 6,7 & 0,0 & 0,0 & 0,0 & 1,5 & 1,8 & 1,5 & 1,1 & 2,0 \\
\hline Onbekend & 0,0 & 0,0 & 0,0 & 5,1 & 4,5 & 0,5 & 1,0 & 0,7 & 1,1 \\
\hline
\end{tabular}

Bron: CBS Microdata. Bewerking door ROA

$\mathrm{x}$ : Onderliggende aantallen zijn kleiner dan 10 en kunnen volgens de richtlijnen van CBS Microdata niet gepubliceerd worden. 


\section{Tabel A3.4}

Stroom van werk naar ww/bijstand, naar opleiding (\%)

\begin{tabular}{|c|c|c|c|c|c|c|c|c|c|}
\hline Jaar & 2011 & 2012 & 2013 & 2014 & 2015 & 2016 & 2017 & 2018 & 2019 \\
\hline \multicolumn{10}{|l|}{ 55-60 jaar } \\
\hline Laagopgeleid & 5,8 & 7,0 & 8,0 & 6,7 & 6,2 & 4,7 & 3,1 & 2,4 & 2,2 \\
\hline Middelbaar opgeleid & 5,6 & 6,9 & 8,5 & 7,1 & 6,4 & 4,5 & 2,9 & 2,2 & 2,0 \\
\hline Hoogopgeleid & 3,3 & 3,9 & 6,6 & 5,8 & 5,9 & 4,5 & 3,4 & 2,9 & 2,6 \\
\hline Onbekend & 0,8 & 1,1 & 0,3 & 0,2 & 0,2 & 0,2 & 0,2 & 0,2 & 0,2 \\
\hline \multicolumn{10}{|l|}{64 jaar } \\
\hline Laagopgeleid & 6,5 & 7,1 & 8,8 & 10,7 & 10,3 & 8,4 & 5,0 & 4,5 & 3,6 \\
\hline Middelbaar opgeleid & 7,1 & 7,3 & 10,2 & 10,8 & 10,2 & 8,7 & 6,0 & 4,1 & 3,8 \\
\hline Hoogopgeleid & 3,1 & 4,1 & 6,2 & 8,2 & 8,6 & 7,7 & 6,4 & 5,1 & 4,0 \\
\hline Onbekend & 0,8 & 1,0 & 0,5 & 0,7 & 1,1 & 0,5 & 0,6 & 0,4 & 0,5 \\
\hline \multicolumn{10}{|l|}{65 jaar } \\
\hline Laagopgeleid & 0,0 & 0,2 & 8,6 & 6,4 & 10,0 & 7,6 & 5,2 & 5,2 & 4,7 \\
\hline Middelbaar opgeleid & 0,0 & 0,2 & 4,4 & 5,2 & 7,9 & 7,8 & 5,9 & 5,2 & 4,6 \\
\hline Hoogopgeleid & 0,1 & 0,2 & 2,9 & 4,6 & 7,5 & 7,0 & 5,3 & 5,5 & 4,9 \\
\hline Onbekend & 0,0 & 0,0 & 0,5 & 0,5 & 1,4 & 1,2 & 1,1 & 0,9 & 0,8 \\
\hline \multicolumn{10}{|l|}{66 jaar } \\
\hline Laagopgeleid & 0,6 & 0,0 & 0,0 & 0,0 & 0,1 & 0,0 & 0,2 & 0,3 & 2,7 \\
\hline Middelbaar opgeleid & 0,0 & 0,4 & 0,0 & 0,0 & 0,0 & 0,0 & 0,1 & 0,3 & 2,5 \\
\hline Hoogopgeleid & 0,0 & 0,0 & 0,0 & 0,0 & 0,3 & 0,0 & 0,1 & 0,3 & 2,4 \\
\hline Onbekend & 0,0 & 0,0 & 0,0 & 0,0 & 0,0 & 0,0 & 0,0 & 0,1 & 0,6 \\
\hline
\end{tabular}

Bron: CBS Microdata. Bewerking door ROA 
Tabel A3.5

Stroom van werk naar ZW, naar opleiding (\%)

\begin{tabular}{|c|c|c|c|c|c|c|c|c|c|}
\hline & 2011 & 2012 & 2013 & 2014 & 2015 & 2016 & 2017 & 2018 & 2019 \\
\hline \multicolumn{10}{|l|}{ 55-60 jaar } \\
\hline Laagopgeleid & 2,4 & 2,3 & 2,6 & 2,3 & 2,2 & 2,0 & 1,9 & 1,8 & 2,0 \\
\hline Middelbaar opgeleid & 1,4 & 1,4 & 1,5 & 1,4 & 1,4 & 1,3 & 1,2 & 1,2 & 1,3 \\
\hline Hoogopgeleid & 0,8 & 0,7 & 0,9 & 0,8 & 0,7 & 0,7 & 0,7 & 0,7 & 0,7 \\
\hline Onbekend & 0,9 & 0,8 & 0,6 & 0,6 & 0,5 & 0,6 & 0,5 & 0,5 & 0,5 \\
\hline \multicolumn{10}{|l|}{64 jaar } \\
\hline Laagopgeleid & 2,6 & 2,0 & 2,6 & 2,1 & 2,5 & 2,5 & 2,5 & 2,4 & 2,7 \\
\hline Middelbaar opgeleid & 1,3 & 1,4 & 1,6 & 1,8 & 1,7 & 1,9 & 1,9 & 2,0 & 1,9 \\
\hline Hoogopgeleid & 0,7 & 0,7 & 0,7 & 0,8 & 0,9 & 1,0 & 1,0 & 1,1 & 0,9 \\
\hline Onbekend & 0,9 & 0,9 & 0,7 & 0,8 & 0,8 & 0,9 & 0,9 & 1,0 & 0,9 \\
\hline \multicolumn{10}{|l|}{65 jaar } \\
\hline Laagopgeleid & 0,0 & 0,2 & 1,7 & 2,4 & 1,8 & 2,3 & 1,9 & 2,2 & 2,4 \\
\hline Middelbaar opgeleid & 0,0 & 0,0 & 0,4 & 0,9 & 1,1 & 1,8 & 1,7 & 1,8 & 1,9 \\
\hline Hoogopgeleid & 0,0 & 0,1 & 1,0 & 0,8 & 0,7 & 0,5 & 1,0 & 1,1 & 1,0 \\
\hline Onbekend & 0,0 & 0,0 & 1,2 & 1,0 & 0,8 & 0,9 & 0,8 & 1,1 & 1,0 \\
\hline \multicolumn{10}{|l|}{66 jaar } \\
\hline Laagopgeleid & 0,0 & 0,0 & 0,0 & 0,0 & 0,0 & 0,0 & 0,0 & 0,1 & 1,0 \\
\hline Middelbaar opgeleid & 0,0 & 0,0 & 0,0 & 0,0 & 0,0 & 0,0 & 0,0 & 0,1 & 1,0 \\
\hline Hoogopgeleid & 0,0 & 0,0 & 0,0 & 0,0 & 0,0 & 0,0 & 0,0 & 0,0 & 0,5 \\
\hline Onbekend & 0,0 & 0,0 & 0,0 & 0,0 & 0,0 & 0,0 & 0,0 & 0,1 & 0,5 \\
\hline
\end{tabular}

Bron: CBS Microdata. Bewerking door ROA 
Tabel A3.6

Stroom van werk naar ww/bijstand, naar inkomensklasse (\%)

\begin{tabular}{|c|c|c|c|c|c|c|c|c|c|}
\hline & 2011 & 2012 & 2013 & 2014 & 2015 & 2016 & 2017 & 2018 & 2019 \\
\hline \multicolumn{10}{|l|}{ 55-60 jaar } \\
\hline o tot minimum & 3,1 & 3,9 & 4,8 & 4,3 & 4,8 & 4,2 & 2,8 & 2,3 & 2,3 \\
\hline minimum tot modaal & 3,3 & 4,4 & 5,2 & 4,4 & 3,9 & 3,1 & 2,1 & 1,7 & 1,7 \\
\hline modaal tot $2 \times$ modaal & 1,9 & 2,6 & 3,1 & 2,3 & 1,8 & 1,4 & 1,0 & 0,9 & 0,9 \\
\hline $2 \times$ modaal of hoger & 1,3 & 1,6 & 2,0 & 2,2 & 2,6 & 2,0 & 1,8 & 1,4 & 1,3 \\
\hline \multicolumn{10}{|l|}{64 jaar } \\
\hline o tot minimum & 2,6 & 3,2 & 3,6 & 3,4 & 5,3 & 5,0 & 2,7 & 2,8 & 2,7 \\
\hline minimum tot modaal & 3,4 & 4,7 & 4,8 & 5,2 & 5,5 & 4,5 & 3,1 & 2,7 & 2,4 \\
\hline modaal tot $2 \times$ modaal & 1,8 & 2,2 & 2,9 & 3,5 & 3,3 & 2,6 & 1,9 & 1,5 & 1,3 \\
\hline $2 \times$ modaal of hoger & 0,9 & 1,1 & 1,2 & 2,7 & 3,6 & 3,1 & 3,4 & 2,6 & 2,3 \\
\hline \multicolumn{10}{|l|}{65 jaar } \\
\hline 0 tot minimum & 0,1 & 0,2 & 1,0 & 1,3 & 2,2 & 2,8 & 2,0 & 3,1 & 2,8 \\
\hline minimum tot modaal & 0,0 & 0,0 & 1,7 & 1,8 & 3,0 & 3,1 & 2,3 & 3,4 & 2,9 \\
\hline modaal tot $2 \times$ modaal & 0,0 & 0,1 & 1,2 & 1,1 & 1,7 & 1,3 & 1,4 & 2,2 & 1,9 \\
\hline $2 \times$ modaal of hoger & 0,0 & 0,1 & 0,3 & 0,4 & 1,2 & 1,3 & 1,3 & 2,6 & 2,9 \\
\hline \multicolumn{10}{|l|}{66 jaar } \\
\hline o tot minimum & 0,5 & 0,7 & 0,0 & 0,0 & 0,2 & 0,0 & 0,4 & 0,6 & 1,3 \\
\hline minimum tot modaal & 0,0 & 0,1 & 0,1 & 0,0 & 0,0 & 0,0 & 0,1 & 0,2 & 0,9 \\
\hline modaal tot $2 \times$ modaal & 0,0 & 0,0 & 0,0 & 0,0 & 0,0 & 0,0 & 0,0 & 0,1 & 0,6 \\
\hline $2 \times$ modaal of hoger & 0,0 & 0,0 & 0,0 & 0,1 & 0,0 & 0,0 & 0,0 & 0,1 & 0,6 \\
\hline
\end{tabular}

Bron: CBS Microdata. Bewerking door ROA 
Tabel A3.7

Stroom van werk naar ZW, naar inkomensklasse (\%)

\begin{tabular}{|c|c|c|c|c|c|c|c|c|c|}
\hline & 2011 & 2012 & 2013 & 2014 & 2015 & 2016 & 2017 & 2018 & 2019 \\
\hline \multicolumn{10}{|l|}{ 55-60 jaar } \\
\hline o tot minimum & 1,6 & 1,5 & 1,4 & 1,4 & 1,5 & 1,5 & 1,6 & 1,6 & 1,6 \\
\hline minimum tot modaal & 2,2 & 2,1 & 2,0 & 1,9 & 1,8 & 1,7 & 1,7 & 1,7 & 1,6 \\
\hline modaal tot $2 \times$ modaal & 0,9 & 0,9 & 1,0 & 0,9 & 0,8 & 0,8 & 0,7 & 0,7 & 0,7 \\
\hline $2 \times$ modaal of hoger & 0,3 & 0,2 & 0,3 & 0,3 & 0,3 & 0,3 & 0,4 & 0,3 & 0,4 \\
\hline \multicolumn{10}{|l|}{64 jaar } \\
\hline o tot minimum & 1,2 & 1,2 & 1,1 & 1,3 & 1,4 & 1,7 & 1,5 & 1,8 & 1,4 \\
\hline minimum tot modaal & 2,4 & 2,3 & 2,2 & 2,1 & 2,0 & 2,4 & 2,3 & 2,3 & 2,2 \\
\hline modaal tot $2 \times$ modaal & 0,9 & 1,0 & 0,9 & 1,0 & 1,1 & 1,1 & 1,2 & 1,3 & 1,2 \\
\hline $2 \times$ modaal of hoger & 0,2 & 0,2 & 0,2 & 0,2 & 0,4 & 0,6 & 0,7 & 0,7 & 0,9 \\
\hline \multicolumn{10}{|l|}{65 jaar } \\
\hline 0 tot minimum & 0,0 & 0,1 & 0,2 & 0,3 & 0,6 & 0,8 & 0,7 & 1,6 & 1,5 \\
\hline minimum tot modaal & 0,0 & 0,1 & 1,5 & 0,7 & 1,1 & 1,1 & 1,1 & 2,3 & 2,0 \\
\hline modaal tot $2 \times$ modaal & 0,0 & 0,0 & 0,6 & 0,9 & 0,4 & 0,6 & 0,6 & 1,4 & 1,2 \\
\hline $2 \times$ modaal of hoger & 0,0 & 0,0 & 0,2 & 0,2 & 0,1 & 0,2 & 0,2 & 0,5 & 0,9 \\
\hline \multicolumn{10}{|l|}{66 jaar } \\
\hline o tot minimum & 0,0 & 0,0 & 0,0 & 0,0 & 0,0 & 0,0 & 0,0 & 0,0 & 0,4 \\
\hline minimum tot modaal & 0,0 & 0,0 & 0,0 & 0,0 & 0,0 & 0,0 & 0,0 & 0,1 & 0,5 \\
\hline modaal tot $2 \times$ modaal & 0,0 & 0,0 & 0,0 & 0,0 & 0,0 & 0,0 & 0,0 & 0,0 & 0,3 \\
\hline $2 \times$ modaal of hoger & 0,0 & 0,0 & 0,0 & 0,0 & 0,0 & 0,0 & 0,0 & 0,1 & 0,2 \\
\hline
\end{tabular}

Bron: CBS Microdata. Bewerking door ROA 


\section{Tabel A4}

Scholing (\%)

\begin{tabular}{|c|c|c|c|c|c|c|c|c|c|c|}
\hline Jaar & 2009 & 2010 & 2011 & 2012 & 2013 & 2014 & 2015 & 2016 & 2017 & 2018 \\
\hline \multicolumn{11}{|l|}{ Leeftijdsklasse $56-60$} \\
\hline Cursus betaald door werkgever & 4,7 & 5,2 & 6,5 & 5,6 & 8,1 & 9,4 & 10,3 & 10,4 & 9,9 & 9,2 \\
\hline Cursus niet betaald door werkgever & 1,4 & 1,4 & 1,7 & 1,2 & 1,9 & 2,3 & 2,8 & 2,8 & 2,3 & 2,8 \\
\hline Totaal & 6,1 & 6,6 & 8,1 & 6,8 & 10,0 & 11,7 & 13,1 & 13,2 & 12,2 & 12,0 \\
\hline \multicolumn{11}{|l|}{ Leeftijdsklasse $61-65$} \\
\hline Cursus betaald door werkgever & 1,4 & 1,7 & 1,5 & 0,9 & 2,2 & 2,1 & 2,7 & 2,5 & 2,2 & 2,3 \\
\hline Cursus niet betaald door werkgever & 2,3 & 3,2 & 3,6 & 3,4 & 5,7 & 6,6 & 7,8 & 7,3 & 7,9 & 7,2 \\
\hline Totaal & 3,7 & 4,9 & 5,1 & 4,3 & 7,9 & 8,6 & 10,5 & 9,7 & 10,1 & 9,6 \\
\hline
\end{tabular}

Bron: CBS Microdata. Bewerking door ROA

\section{Tabel A5}

Scholing naar opleidingsniveau (\%)

\begin{tabular}{|c|c|c|c|c|c|c|c|c|c|c|}
\hline Jaar & 2009 & 2010 & 2011 & 2012 & 2013 & 2014 & 2015 & 2016 & 2017 & 2018 \\
\hline \multicolumn{11}{|l|}{ Leeftijdsklasse $56-60$} \\
\hline Laagopgeleid & 3,6 & 3,5 & 5,1 & 3,5 & 5,6 & 8,3 & 7,4 & 7,0 & 7,2 & 8,2 \\
\hline Middelbaar opgeleid & 5,8 & 7,2 & 8,5 & 7,4 & 10,9 & 11,3 & 13,3 & 13,6 & 12,2 & 11,4 \\
\hline Hoogopgeleid & 8,7 & 8,8 & 10,6 & 8,9 & 12,5 & 15,1 & 17,6 & 18,1 & 16,0 & 15,5 \\
\hline \multicolumn{11}{|l|}{ Leeftijdsklasse 61-65 } \\
\hline Laagopgeleid & 1,9 & 2,6 & 3,3 & 2,9 & 3,5 & 5,5 & 6,0 & 6,1 & 6,4 & 5,3 \\
\hline Middelbaar opgeleid & 3,3 & 4,3 & 5,3 & 3,8 & 8,4 & 8,1 & 9,7 & 9,0 & 11,4 & 9,6 \\
\hline Hoogopgeleid & 5,9 & 7,6 & 6,8 & 6,0 & 11,4 & 12,2 & 15,6 & 14,3 & 12,1 & 13,3 \\
\hline
\end{tabular}

Bron: CBS Microdata. Bewerking door ROA 


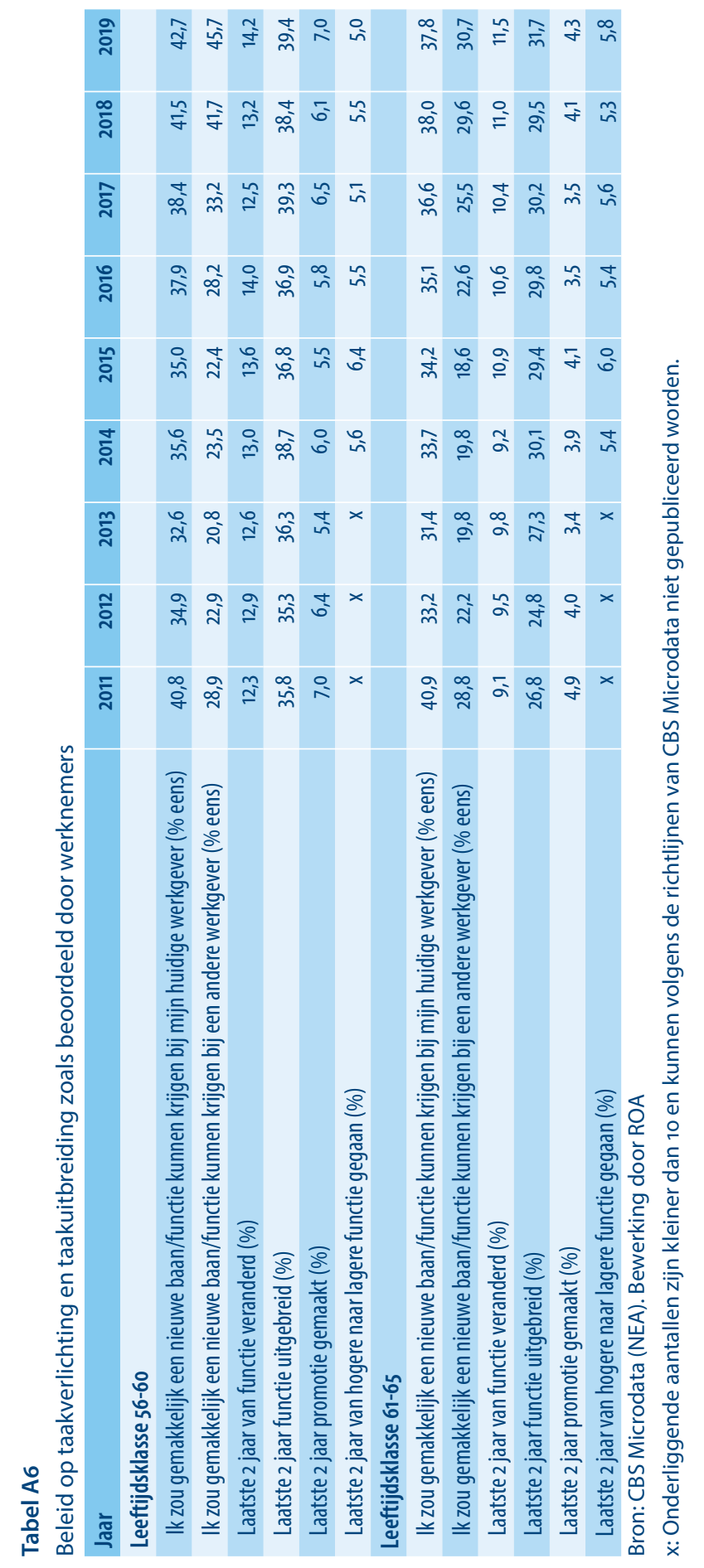


Tabel A7

Inkomensbron (\%)

\begin{tabular}{|c|c|c|c|c|c|c|c|c|c|c|}
\hline & & 2011 & 2012 & 2013 & 2014 & 2015 & 2016 & 2017 & 2018 & 2019 \\
\hline \multirow[t]{6}{*}{64 jaar } & Loondienst/eigen onderneming & 18,9 & 20,8 & 23,1 & 32,9 & 35,4 & 38,3 & 41,6 & 45,0 & 48,3 \\
\hline & Bijstand/WW & 4,9 & 5,1 & 5,4 & 7,7 & 8,5 & 8,7 & 8,4 & 7,8 & 7,0 \\
\hline & ZW/WIA & 13,1 & 12,5 & 12,2 & 12,9 & 12,9 & 13,1 & 12,9 & 12,8 & 12,6 \\
\hline & AOW/pensioen & 42,6 & 41,8 & 40,2 & 26,6 & 23,5 & 21,1 & 20,0 & 17,9 & 16,4 \\
\hline & Overig inkomen & 2,4 & 2,5 & 2,7 & 3,1 & 3,2 & 3,3 & 3,1 & 3,3 & 3,5 \\
\hline & Geen inkomen & 18,0 & 17,1 & 16,3 & 16,8 & 16,5 & 15,4 & 14,1 & 13,1 & 12,2 \\
\hline \multirow[t]{6}{*}{65 jaar } & Loondienst/eigen onderneming & 6,0 & 6,3 & 7,0 & 8,7 & 14,7 & 21,2 & 28,6 & 35,9 & 39,2 \\
\hline & Bijstand/WW & 0,2 & 0,3 & 0,7 & 1,1 & 2,4 & 4,5 & 6,6 & 7,9 & 7,2 \\
\hline & ZW/WIA & 0,0 & 0,4 & 1,2 & 2,1 & 3,4 & 6,7 & 10,3 & 13,1 & 13,1 \\
\hline & AOW/pensioen & 93,2 & 92,4 & 89,5 & 84,9 & 74,3 & 57,6 & 40,6 & 25,9 & 24,1 \\
\hline & Overig inkomen & 0,4 & 0,5 & 0,6 & 0,9 & 1,2 & 2,0 & 2,7 & 3,6 & 3,8 \\
\hline & Geen inkomen & 0,2 & 0,2 & 1,0 & 2,3 & 4,0 & 7,9 & 11,2 & 13,5 & 12,6 \\
\hline \multirow[t]{6}{*}{66 jaar } & Loondienst/eigen onderneming & 4,7 & 4,9 & 4,8 & 5,0 & 5,3 & 6,9 & 7,6 & 10,0 & 18,6 \\
\hline & Bijstand/WW & 0,1 & 0,1 & 0,1 & 0,1 & 0,1 & 0,2 & 0,7 & 1,1 & 3,1 \\
\hline & ZW/WIA & 0,0 & 0,0 & 0,0 & 0,0 & 0,0 & 0,0 & 0,0 & 0,5 & 4,6 \\
\hline & AOW/pensioen & 94,6 & 94,6 & 94,6 & 94,5 & 94,1 & 92,5 & 91,4 & 87,8 & 67,7 \\
\hline & Overig inkomen & 0,4 & 0,4 & 0,4 & 0,4 & 0,3 & 0,3 & 0,1 & 0,3 & 1,7 \\
\hline & Geen inkomen & 0,1 & 0,1 & 0,1 & 0,1 & 0,1 & 0,2 & 0,2 & 0,2 & 4,3 \\
\hline
\end{tabular}

Bron: CBS Microdata. Bewerking door ROA 
Tabel A7.2

Inkomensbron naar opleiding (\%)

\begin{tabular}{|c|c|c|c|c|c|c|c|c|c|c|}
\hline & & 2011 & 2012 & 2013 & 2014 & 2015 & 2016 & 2017 & 2018 & 2019 \\
\hline \multicolumn{11}{|l|}{64 jaar } \\
\hline \multirow[t]{6}{*}{ Laagopgeleid } & $\begin{array}{l}\text { Loondienst /eigen } \\
\text { onderneming }\end{array}$ & 13,6 & 14,8 & 17,0 & 25,3 & 26,9 & 29,8 & 33,1 & 36,3 & 37,7 \\
\hline & Bijstand/WW & 6,0 & 6,4 & 7,6 & 10,2 & 11,0 & 12,0 & 11,1 & 10,7 & 10,4 \\
\hline & ZW/WIA & 16,5 & 16,1 & 15,1 & 16,2 & 16,8 & 17,4 & 16,9 & 16,8 & 16,9 \\
\hline & AOW/pensioen & 33,6 & 32,6 & 33,0 & 21,2 & 18,5 & 16,6 & 15,0 & 13,1 & 12,3 \\
\hline & Overig inkomen & 2,2 & 2,6 & 3,1 & 3,3 & 3,4 & 3,2 & 3,4 & 3,5 & 4,2 \\
\hline & Geen inkomen & 28,0 & 27,5 & 24,1 & 23,9 & 23,4 & 20,9 & 20,5 & 19,6 & 18,4 \\
\hline \multirow[t]{6}{*}{$\begin{array}{l}\text { Middelbaar } \\
\text { opgeleid }\end{array}$} & $\begin{array}{l}\text { Loondienst /eigen } \\
\text { onderneming }\end{array}$ & 18,6 & 21,8 & 23,4 & 35,9 & 37,8 & 41,6 & 44,3 & 48,4 & 51,0 \\
\hline & Bijstand/WW & 3,5 & 3,8 & 4,2 & 6,1 & 7,1 & 7,1 & 6,5 & 5,4 & 5,0 \\
\hline & ZW/WIA & 13,1 & 12,0 & 12,2 & 12,2 & 12,5 & 12,6 & 12,9 & 12,4 & 12,4 \\
\hline & AOW/pensioen & 45,5 & 43,8 & 43,7 & 29,6 & 25,6 & 21,8 & 20,8 & 18,6 & 16,6 \\
\hline & Overig inkomen & 2,1 & 2,3 & 2,3 & 2,9 & 3,0 & 3,1 & 2,8 & 3,1 & 3,1 \\
\hline & Geen inkomen & 17,2 & 16,4 & 14,2 & 13,3 & 14,1 & 13,8 & 12,7 & 12,1 & 12,0 \\
\hline \multirow[t]{6}{*}{ Hoogopgeleid } & $\begin{array}{l}\text { Loondienst /eigen } \\
\text { onderneming }\end{array}$ & 24,5 & 27,3 & 29,5 & 42,0 & 42,2 & 47,1 & 47,5 & 51,1 & 54,3 \\
\hline & Bijstand/WW & 3,1 & 3,3 & 3,1 & 5,3 & 6,7 & 6,7 & 7,1 & 6,6 & 5,5 \\
\hline & ZW/WIA & 9,3 & 9,0 & 7,2 & 8,4 & 8,5 & 7,5 & 8,5 & 7,8 & 7,6 \\
\hline & AOW/pensioen & 52,5 & 49,7 & 50,1 & 33,5 & 30,3 & 26,6 & 26,3 & 23,4 & 22,4 \\
\hline & Overig inkomen & 1,1 & 1,5 & 1,6 & 2,8 & 2,9 & 2,8 & 1,9 & 2,4 & 2,4 \\
\hline & Geen inkomen & 9,4 & 9,1 & 8,5 & 8,0 & 9,5 & 9,3 & 8,7 & 8,7 & 7,6 \\
\hline 65 jaar & & 2011 & 2012 & 2013 & 2014 & 2015 & 2016 & 2017 & 2018 & 2019 \\
\hline \multirow[t]{6}{*}{ Laagopgeleid } & $\begin{array}{l}\text { Loondienst /eigen } \\
\text { onderneming }\end{array}$ & 3,8 & 4,0 & 5,3 & 6,7 & 11,1 & 16,6 & 22,9 & 29,9 & 32,8 \\
\hline & Bijstand/WW & 0,4 & 0,4 & 1,0 & 1,5 & 3,2 & 6,3 & 9,7 & 10,9 & 10,4 \\
\hline & ZW/WIA & 0,0 & 0,6 & 1,5 & 2,6 & 4,0 & 8,6 & 12,7 & 16,6 & 16,5 \\
\hline & AOW/pensioen & 95,6 & 94,7 & 89,9 & 85,1 & 75,3 & 54,7 & 35,8 & 18,8 & 16,8 \\
\hline & Overig inkomen & 0,2 & 0,3 & 0,6 & 0,9 & 1,1 & 1,8 & 2,9 & 3,9 & 3,9 \\
\hline & Geen inkomen & 0,1 & 0,1 & 1,8 & 3,2 & 5,3 & 11,9 & 16,0 & 19,8 & 19,5 \\
\hline \multirow[t]{6}{*}{$\begin{array}{l}\text { Middelbaar } \\
\text { opgeleid }\end{array}$} & $\begin{array}{l}\text { Loondienst/eigen } \\
\text { onderneming }\end{array}$ & 7,2 & 7,1 & 7,4 & 9,6 & 17,1 & 23,7 & 31,7 & 39,1 & 42,5 \\
\hline & Bijstand/WW & 0,1 & 0,2 & 0,4 & 0,8 & 1,8 & 3,5 & 5,0 & 5,8 & 5,0 \\
\hline & ZW/WIA & 0,0 & 0,4 & 1,2 & 2,1 & 3,2 & 6,7 & 9,9 & 13,0 & 12,2 \\
\hline & AOW/pensioen & 92,1 & 91,9 & 89,9 & 84,7 & 73,4 & 56,6 & 40,8 & 26,6 & 25,3 \\
\hline & Overig inkomen & 0,5 & 0,4 & 0,4 & 0,9 & 1,2 & 2,0 & 2,6 & 3,5 & 3,7 \\
\hline & Geen inkomen & 0,1 & 0,1 & 0,8 & 1,8 & 3,3 & 7,5 & 10,0 & 11,9 & 11,3 \\
\hline \multirow[t]{3}{*}{ Hoogopgeleid } & $\begin{array}{l}\text { Loondienst/eigen } \\
\text { onderneming }\end{array}$ & 8,2 & 8,5 & 9,0 & 12,3 & 20,0 & 25,8 & 34,6 & 40,1 & 43,2 \\
\hline & Bijstand/WW & 0,2 & 0,4 & 0,5 & 0,6 & 1,5 & 3,1 & 5,2 & 6,6 & 5,6 \\
\hline & ZW/WIA & 0,0 & 0,3 & 1,1 & 1,3 & 2,6 & 4,2 & 6,1 & 8,5 & 7,9 \\
\hline
\end{tabular}




\begin{tabular}{|c|c|c|c|c|c|c|c|c|c|c|}
\hline & & 2011 & 2012 & 2013 & 2014 & 2015 & 2016 & 2017 & 2018 & 2019 \\
\hline & AOW/pensioen & 91,2 & 90,3 & 88,0 & 84,4 & 72,2 & 60,5 & 45,7 & 34,2 & 33,1 \\
\hline & Overig inkomen & 0,3 & 0,4 & 0,8 & 0,8 & 0,9 & 1,6 & 1,6 & 2,5 & 2,6 \\
\hline & Geen inkomen & 0,1 & 0,1 & 0,7 & 0,7 & 2,7 & 4,9 & 6,9 & 8,0 & 7,6 \\
\hline 66 jaar & & 2011 & 2012 & 2013 & 2014 & 2015 & 2016 & 2017 & 2018 & 2019 \\
\hline \multirow[t]{6}{*}{ Laagopgeleid } & $\begin{array}{l}\text { Loondienst/eigen } \\
\text { onderneming }\end{array}$ & 2,7 & 3,3 & 3,3 & 3,5 & 3,9 & 4,8 & 5,2 & 7,2 & 14,3 \\
\hline & Bijstand/WW & 0,2 & 0,1 & 0,1 & 0,1 & 0,1 & 0,2 & 1,2 & 2,2 & 4,4 \\
\hline & ZW/WIA & 0,0 & 0,0 & 0,0 & 0,0 & 0,0 & 0,0 & 0,0 & 0,6 & 5,7 \\
\hline & AOW/pensioen & 96,8 & 96,5 & 96,3 & 96,1 & 95,7 & 94,6 & 93,3 & 89,3 & 68,0 \\
\hline & Overig inkomen & 0,3 & 0,2 & 0,3 & 0,3 & 0,3 & 0,3 & 0,2 & 0,5 & 1,7 \\
\hline & Geen inkomen & 0,0 & 0,0 & 0,0 & 0,0 & 0,0 & 0,1 & 0,1 & 0,1 & 6,0 \\
\hline \multirow[t]{6}{*}{$\begin{array}{l}\text { Middelbaar } \\
\text { opgeleid }\end{array}$} & $\begin{array}{l}\text { Loondienst/eigen } \\
\text { onderneming }\end{array}$ & 5,0 & 5,9 & 5,4 & 5,6 & 5,6 & 8,1 & 8,9 & 11,8 & 21,6 \\
\hline & Bijstand/WW & 0,1 & 0,1 & 0,0 & 0,0 & 0,0 & 0,0 & 0,2 & 0,6 & 2,0 \\
\hline & ZW/WIA & 0,0 & 0,0 & 0,0 & 0,0 & 0,0 & 0,0 & 0,0 & 0,4 & 4,5 \\
\hline & AOW/pensioen & 94,5 & 93,5 & 94,1 & 94,1 & 94,0 & 91,2 & 90,7 & 86,6 & 66,5 \\
\hline & Overig inkomen & 0,5 & 0,4 & 0,4 & 0,3 & 0,4 & 0,3 & 0,1 & 0,4 & 1,7 \\
\hline & Geen inkomen & 0,0 & 0,0 & 0,1 & 0,0 & 0,0 & 0,4 & 0,1 & 0,3 & 3,7 \\
\hline \multirow[t]{6}{*}{ Hoogopgeleid } & $\begin{array}{l}\text { Loondienst/eigen } \\
\text { onderneming }\end{array}$ & 5,6 & 6,3 & 6,0 & 5,8 & 7,4 & 9,0 & 9,2 & 12,9 & 20,4 \\
\hline & Bijstand/WW & 0,0 & 0,1 & 0,0 & 0,1 & 0,1 & 0,0 & 0,3 & 0,8 & 2,7 \\
\hline & ZW/WIA & 0,0 & 0,0 & 0,0 & 0,0 & 0,0 & 0,0 & 0,0 & 0,3 & 2,9 \\
\hline & AOW/pensioen & 94,0 & 93,2 & 93,5 & 93,2 & 92,1 & 90,1 & 90,2 & 85,5 & 70,2 \\
\hline & Overig inkomen & 0,4 & 0,4 & 0,4 & 0,8 & 0,3 & 0,3 & 0,1 & 0,3 & 1,3 \\
\hline & Geen inkomen & 0,1 & 0,1 & 0,0 & 0,2 & 0,0 & 0,5 & 0,2 & 0,2 & 2,6 \\
\hline
\end{tabular}

Bron: CBS Microdata. Bewerking door ROA

\section{Tabel A8}

Gemiddeld bruto persoonlijk inkomen

\begin{tabular}{|c|c|c|c|c|c|c|c|c|c|c|c|}
\hline & 2009 & 2010 & 2011 & 2012 & 2013 & 2014 & 2015 & 2016 & 2017 & 2018 & 2019 \\
\hline 64-jarigen & 27521 & 28949 & 29800 & 30492 & 31206 & 33496 & 33807 & 35094 & 37621 & 37909 & 39715 \\
\hline 65 -jarigen & 27250 & 27485 & 28918 & 29197 & 29491 & 30138 & 30598 & 32230 & 35072 & 35558 & 37678 \\
\hline 66-jarigen & 25214 & 25784 & 25842 & 26843 & 26837 & 27510 & 27616 & 28626 & 31098 & 31110 & 33927 \\
\hline
\end{tabular}




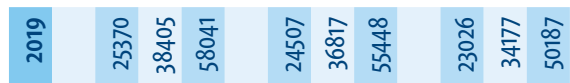

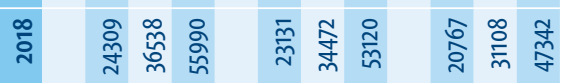

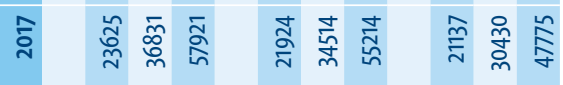

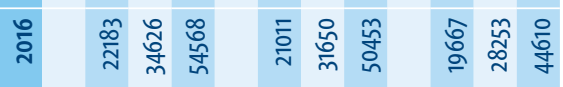

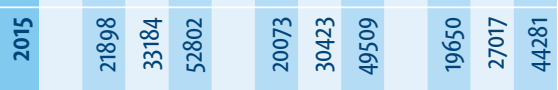

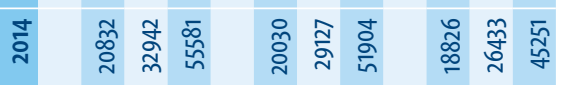

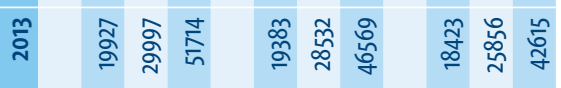

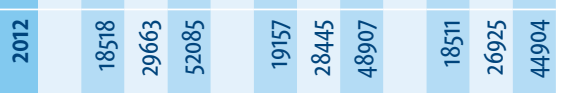

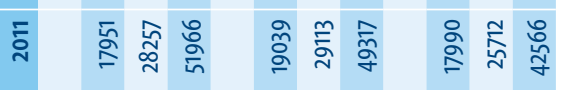

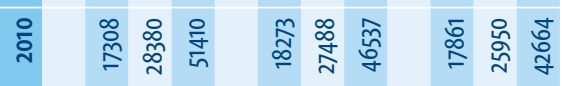

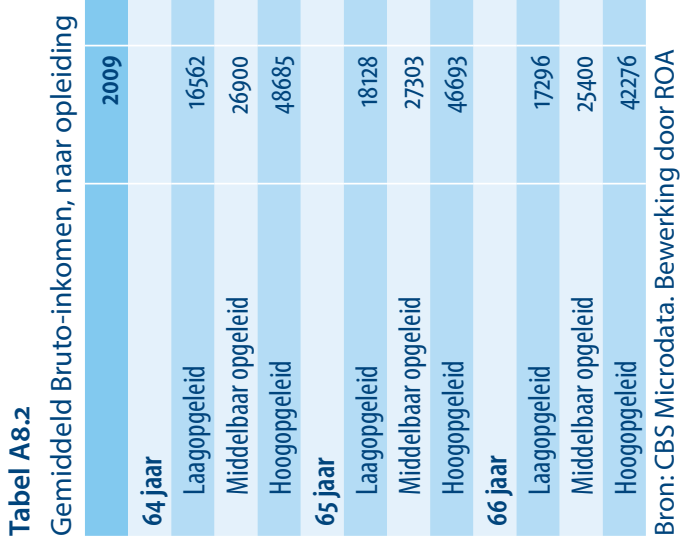


Tabel A9

Kunnen voldoen aan eisen werk (\%)

\begin{tabular}{|c|c|c|c|c|}
\hline Jaar & 2012 & 2015 & 2017 & 2019 \\
\hline \multicolumn{5}{|c|}{ Makkelijk kunnen voldoen aan de fysieke eisen van hun werk } \\
\hline \multicolumn{5}{|l|}{ Werknemers } \\
\hline Leeftijdsklasse 56-60 & 83,3 & 84,8 & 83,0 & 84,9 \\
\hline Leeftijdsklasse 61-65 & 82,6 & 81,8 & 80,5 & 81,4 \\
\hline \multicolumn{5}{|l|}{ Zelfstandigen } \\
\hline Leeftijdsklasse 56-60 & 82,9 & 81,1 & 78,9 & 81,8 \\
\hline Leeftijdsklasse 61-65 & 84,0 & 79,7 & 74,8 & 80,5 \\
\hline \multicolumn{5}{|c|}{ Makkelijk kunnen voldoen aan de psychische eisen van hun werk } \\
\hline \multicolumn{5}{|l|}{ Werknemers } \\
\hline Leeftijdsklasse $56-60$ & 86,9 & 87,3 & 84,9 & 88,6 \\
\hline Leeftijdsklasse 61-65 & 85,8 & 85,8 & 85,5 & 86,5 \\
\hline \multicolumn{5}{|l|}{ Zelfstandigen } \\
\hline Leeftijdsklasse 56-60 & 89,2 & 84,8 & 82,5 & 87,2 \\
\hline Leeftijdsklasse 61-65 & 89,1 & 84,3 & 82,2 & 84,8 \\
\hline
\end{tabular}

Bron: CBS Microdata (NEA). Bewerking door ROA 


\section{Tabel A 9}

Kunnen voldoen aan eisen werk, naar opleiding (\%)

\begin{tabular}{|c|c|c|c|c|c|}
\hline Jaar & & 2012 & 2015 & 2017 & 2019 \\
\hline \multicolumn{6}{|c|}{ Makkelijk kunnen voldoen aan de fysieke eisen van hun werk } \\
\hline \multicolumn{6}{|l|}{ Werknemers } \\
\hline Laagopgeleid & Leeftijdsklasse 56-60 & 78,9 & 80,2 & 75,2 & 78,0 \\
\hline Laagopgeleid & Leeftijdsklasse 61-65 & 77,4 & 78,0 & 73,7 & 76,6 \\
\hline Middelbaar opgeleid & Leeftijdsklasse 56-60 & 83,0 & 83,8 & 81,6 & 83,7 \\
\hline Middelbaar opgeleid & Leeftijdsklasse $61-65$ & 84,4 & 80,7 & 79,3 & 80,2 \\
\hline Hoogopgeleid & Leeftijdsklasse 56-60 & 88,4 & 90,1 & 91,7 & 91,9 \\
\hline Hoogopgeleid & Leeftijdsklasse $61-65$ & 86,9 & 87,5 & 88,8 & 88,9 \\
\hline \multicolumn{6}{|l|}{ Zelfstandigen } \\
\hline Laagopgeleid & Leeftijdsklasse 56-60 & 76,1 & 76,6 & 73,7 & 79,4 \\
\hline Laagopgeleid & Leeftijdsklasse 61-65 & 80,1 & 71,9 & 73,4 & 72,8 \\
\hline Middelbaar opgeleid & Leeftijdsklasse 56-60 & 79,2 & 78,9 & 76,3 & 77,5 \\
\hline Middelbaar opgeleid & Leeftijdsklasse 61-65 & 80,5 & 80,2 & 71,0 & 78,1 \\
\hline Hoogopgeleid & Leeftijdsklasse 56-60 & 90,6 & 85,2 & 83,7 & 87,4 \\
\hline Hoogopgeleid & Leeftijdsklasse 61-65 & 90,4 & 83,8 & 79,6 & 87,3 \\
\hline \multicolumn{6}{|c|}{ Makkelijk kunnen voldoen aan de psychische eisen van hun werk } \\
\hline \multicolumn{6}{|l|}{ Werknemers } \\
\hline Laagopgeleid & Leeftijdsklasse 56-60 & 85,2 & 85,9 & 82,7 & 87,3 \\
\hline Laagopgeleid & Leeftijdsklasse 61-65 & 83,5 & 85,9 & 83,6 & 86,9 \\
\hline Middelbaar opgeleid & Leeftijdsklasse 56-60 & 88,3 & 88,0 & 86,2 & 89,6 \\
\hline Middelbaar opgeleid & Leeftijdsklasse 61-65 & 86,6 & 87,1 & 86,6 & 87,3 \\
\hline Hoogopgeleid & Leeftijdsklasse 56-60 & 87,4 & 87,8 & 85,4 & 88,9 \\
\hline Hoogopgeleid & Leeftijdsklasse 61-65 & 87,5 & 84,6 & 86,3 & 86,0 \\
\hline \multicolumn{6}{|l|}{ Zelfstandigen } \\
\hline Laagopgeleid & Leeftijdsklasse 56-60 & 89,3 & 86,9 & 79,7 & 88,5 \\
\hline Laagopgeleid & Leeftijdsklasse $61-65$ & 83,5 & 79,3 & 77,5 & 79,3 \\
\hline Middelbaar opgeleid & Leeftijdsklasse 56-60 & 87,4 & 83,9 & 81,9 & 85,1 \\
\hline Middelbaar opgeleid & Leeftijdsklasse $61-65$ & 87,7 & 86,9 & 80,7 & 83,9 \\
\hline Hoogopgeleid & Leeftijdsklasse 56-60 & 90,8 & 84,9 & 84,4 & 89,1 \\
\hline Hoogopgeleid & Leeftijdsklasse $61-65$ & 94,8 & 85,1 & 85,7 & 88,1 \\
\hline
\end{tabular}

Bron: CBS Microdata (NEA). Bewerking door ROA

\section{Tabel A10}

Ervaren gezondheid (\%)

\begin{tabular}{|c|c|c|c|c|c|c|c|c|c|c|}
\hline & 2010 & 2011 & 2012 & 2013 & 2014 & 2015 & 2016 & 2017 & 2018 & 2019 \\
\hline 64-jarigen & 62,5 & 74,9 & 63,4 & 60,0 & 66,3 & 61,1 & 62,4 & 67,0 & 61,1 & 60,0 \\
\hline 65 -jarigen & 68,5 & 70,0 & 65,4 & 64,9 & 67,8 & 70,5 & 62,0 & 70,2 & 69,1 & 71,2 \\
\hline 66-jarigen & 65,1 & 73,2 & 64,1 & 71,1 & 67,6 & 74,6 & 70,4 & 72,9 & 70,8 & 69,2 \\
\hline
\end{tabular}

Bron: CBS Microdata. Bewerking door ROA 


\section{Tabel A11}

Ervaren gezondheid naar opleidingsniveau (\%)

\begin{tabular}{|c|c|c|c|c|c|c|c|c|c|c|}
\hline Jaar & 2010 & 2011 & 2012 & 2013 & 2014 & 2015 & 2016 & 2017 & 2018 & 2019 \\
\hline \multicolumn{11}{|l|}{ Leeftijdsklasse 56-60 } \\
\hline Laagopgeleid & 59,8 & 63,1 & 60,3 & 61,4 & 64,3 & 63,2 & 63,5 & 56,5 & 55,9 & 59,1 \\
\hline Middelbaar opgeleid & 68,4 & 69,7 & 70,0 & 71,2 & 69,5 & 70,1 & 75,7 & 69,2 & 73,7 & 71,3 \\
\hline Hoogopgeleid & 81,9 & 79,5 & 75,0 & 80,4 & 78,0 & 80,6 & 80,3 & 81,6 & 81,4 & 78,7 \\
\hline \multicolumn{11}{|l|}{ Leeftijdsklasse $61-65$} \\
\hline Laagopgeleid & 63,5 & 62,1 & 62,3 & 56,5 & 60,6 & 50,8 & 54,2 & 53,4 & 47,8 & 59,0 \\
\hline Middelbaar opgeleid & 75,1 & 74,9 & 67,6 & 65,3 & 63,3 & 70,0 & 72,8 & 68,6 & 62,0 & 71,1 \\
\hline Hoogopgeleid & 76,2 & 77,6 & 75,3 & 76,8 & 78,3 & 77,9 & 79,8 & 69,5 & 78,3 & 72,8 \\
\hline
\end{tabular}

Bron: CBS Microdata. Bewerking door ROA

\section{Tabel A12}

Gezonde levensverwachting in jaren

\begin{tabular}{|c|c|c|c|c|c|c|c|c|c|c|c|c|c|}
\hline laar & 2007 & 2008 & 2009 & 2010 & 2011 & 2012 & 2013 & 2014 & 2015 & 2016 & 2017 & 2018 & 2019 \\
\hline \multicolumn{14}{|c|}{ Levensverwachting in als goed ervaren gezondheid } \\
\hline Mannen - 60 jaar & 14 & 13,3 & 14,5 & 14,1 & 13,7 & 14 & 14,2 & 14,2 & 14,5 & 14,8 & 15 & 14,5 & 15,1 \\
\hline Mannen - 65 jaar & 11,2 & 10,4 & 11,6 & 11,3 & 10,9 & 11,2 & 11,5 & 11,5 & 11,7 & 11,8 & 12,2 & 12 & 12,4 \\
\hline Mannen - 70 jaar & 8,6 & 7,6 & 8,9 & 8,7 & 8,3 & 8,6 & 8,9 & 8,5 & 8,8 & 8,8 & 9,2 & 9 & 9,4 \\
\hline Vrouwen - 60 jaar & 14,4 & 14,4 & 14 & 14,2 & 14,4 & 14 & 14,4 & 14,9 & 14,9 & 15,5 & 15,7 & 15,2 & 15,4 \\
\hline Vrouwen - 65 jaar & 11,5 & 11,4 & 11,2 & 11,1 & 11,3 & 11,2 & 11,6 & 11,9 & 12,2 & 12,7 & 13,2 & 12,6 & 12,4 \\
\hline Vrouwen - 70 jaar & 8,7 & 8,5 & 8,4 & 8,3 & 8,4 & 8,6 & 8,5 & 9,2 & 9,2 & 9,9 & 10,3 & 9,7 & 9,6 \\
\hline \multicolumn{14}{|c|}{ Levensverwachting in goede geestelijke gezondheid } \\
\hline Mannen - 60 jaar & 19,4 & 19,9 & 20,2 & 20 & 20,5 & 20,5 & 20,4 & 20,9 & 21,2 & 21,3 & 21,7 & 20,8 & 21,6 \\
\hline Mannen - 65 jaar & 15,6 & 16,1 & 16,4 & 16,2 & 16,9 & 16,8 & 16,6 & 17,4 & 17,5 & 17,5 & 17,9 & 17,3 & 17,8 \\
\hline Mannen - 70 jaar & 12,3 & 12,5 & 13 & 12,7 & 13,3 & 13,1 & 12,9 & 13,6 & 13,9 & 13,9 & 14,1 & 13,8 & 14 \\
\hline Vrouwen - 60 jaar & 21,3 & 21,6 & 21,5 & 21,6 & 21,8 & 22 & 22,1 & 22,5 & 22,3 & 21,9 & 22,1 & 22,1 & 22,6 \\
\hline Vrouwen - 65 jaar & 17,5 & 17,8 & 17,7 & 17,7 & 18,1 & 18,1 & 18,4 & 18,6 & 18,7 & 18,1 & 18,5 & 18,5 & 18,8 \\
\hline Vrouwen - 70 jaar & 14 & 14,1 & 13,7 & 13,9 & 14,6 & 14,5 & 14,7 & 14,9 & 15 & 14,6 & 14,8 & 14,7 & 15 \\
\hline
\end{tabular}

Bron: CBS Microdata. Bewerking door ROA 


\section{Appendix B: Gebruikte databestanden}

De huidige monitor wordt net zoals de vorige monitor gevuld met data die periodiek beschikbaar zijn. Bij het CBS zijn administratieve data jaarlijks beschikbaar op basis van gegevens van de belastingdienst, UWV en gemeenten over werk, inkomstenbron (werk, uitkering, pensioen), hoogte van het inkomen en vermogen. Deze gegevens worden aangevuld met informatie uit enquêtes die jaarlijks worden uitgezet.

In de huidige monitor wordt de periode 2007-2019 in beeld gebracht voor de groep 55-75jarigen die op 31 december van elk jaar in Nederland wonen. De volgende bestanden zijn gebruikt.

1. Inkomensbronnen (SECMBUS). Dit is een CBS-microdatabestand met per persoon alle inkomensbronnen (loondienst, eigen bedrijf, uitkering) en de belangrijkste inkomensbron. De SECMBUS is beschikbaar voor alle jaren tussen 2007 en 2019.

2. Hoogte van het inkomen. Hiervoor wordt gebruikgemaakt van de CBS-microdatabestanden IPI en INPATAB. Dit bestand bevat onder andere informatie over de hoogte van het inkomen uit arbeid (loon en inkomen als zelfstandige), inkomen uit uitkering (naar type uitkering, waaronder pensioen en lijfrente) en inkomen uit vermogen. Ook bevat het bestand informatie over de koopkracht van personen. IPI is beschikbaar voor de jaren 2007 tot en met 2010. INPATAB is beschikbaar van 2011 tot en met 2019.

3. Enquête beroepsbevolking (EBB). Deze enquête bevat periodieke informatie over beroepen en inkomen. Het geeft een beeld van de koppeling tussen beroep en inkomen op verschillende dimensies, zoals de leeftijdssamenstelling binnen beroepen/beroepsgroepen en de investeringen in scholing. Ook wordt duidelijk wie niet werkt en wat de reden daarvoor is. De EBB is beschikbaar voor alle jaren (20072019)

4. Nederlandse Enquête Arbeidsomstandigheden (NEA). Dit is een enquête van TNO en CBS onder werknemers tussen de 15 en 65 jaar (2003-2013) of tussen de 15 en 75 jaar (vanaf 2014). De vragenlijst bevat onder andere vragen over werktijden, werkdruk, emotionele en fysieke werkbelasting, gezondheid, chronische ziekten, functioneren en inzetbaarheid, opleiding en ontwikkeling. In 2014 is de steekproef vergroot van 80.000 naar 140.000 werknemers. De NEA is beschikbaar voor de jaren 2005-2019. De NEA wordt bekeken vanaf 2010, omdat in 2008 de vragen over het inzetten van maatregelen voor ouderen niet ingevuld waren.

5. Werkgeversenquête arbeid (WEA). De WEA is een enquête van TNO en CBS onder werkgevers met ten minste twee werknemers. De vragenlijst wordt jaarlijks ingevuld door 5.000 werkgevers. De vragenlijst bevat onder andere vragen over de maatregelen die werkgevers nemen om werknemers inzetbaar te houden. De WEA is 
beschikbaar van 2008 tot en met 2016 en is sinds de laatste monitor niet geüpdated. Derhalve laat deze rapportage geen nieuwe resultaten zien op basis van de WEA.

6. Zelfstandigen Enquête Arbeid (ZEA). De ZEA is een enquête van TNO en CBS onder zesduizend zelfstandig ondernemers over arbeidsomstandigheden en inzetbaarheid van zelfstandigen. De vragen komen deels overeen met de NEA-vragenlijst. De enquête is als pilot uitgevoerd in 2012 en daarna in 2015, 2017 en 2019. Deze enquête wordt elke twee jaar herhaald.

7. Gezondheidsenquête. De gezondheidsenquête is een enquête die inzicht geeft in de ontwikkelingen in de gezondheid, de medische contacten, de leefstijl en het preventieve gedrag van de bevolking in Nederland. De ondervraagde personen zijn o jaar en ouder die woonachtig in Nederland zijn. De gezondheidsenquête is van 2010 tot 2019 beschikbaar en wordt elk jaar herhaald.

8. Pensioenaanspraken Statistiek (PAS). Dit bestand bevat per persoon de hoogte van hun tweede-pijler pensioenaanspraak. PAS is beschikbaar voor 2015 en 2016.

9. GBAPERSOONTAB. Persoonskenmerken van alle in de GBA ingeschreven personen. GBAPERSOONTAB is gebruikt om de populatie te bepalen en hun leeftijd te bepalen. Voor dit onderzoek is gebruikgemaakt van de 2019-versie van het GBAPERSOONTAB.

10. GBAADRESOBJECTBUS. Adreskenmerken van personen die in de gemeentelijke bevolkingsregisters ingeschreven (hebben ge)staan. Door het GBAADRESOBJECTBUS te koppelen aan het GBAPERSOONTAB kan per jaar een selectie gemaakt worden van de personen die in Nederland woonachtig zijn. GBAADRESOBJECTBUS is beschikbaar voor de gehele periode (2007-2019). 


\section{Appendix C: Inhoud van de monitor}

De monitor bevat de volgende variabelen voor de periode 2007-2019:

\section{Wensen en mogelijkheden}

- Tot welke leeftijd (fysiek en geestelijk) kunnen werken (NEA/ZEA 55-65 jaar)

- Tot welke leeftijd willen doorwerken en verwachten door te kunnen werken (NEA/ ZEA 55-65 jaar)

\section{Intermediaire effecten (stromen)}

Stromen in en uit werk (CBS), op basis van belangrijkste inkomstenbron

- $\%$ uitstroom uit werk naar

- ZW/WIA

- WW

- Bijstand (uitsplitsen naar zelfstandigen en loondienst)

- Pensioen (uitsplitsen naar zelfstandigen en loondienst)

- Geen inkomen (uitsplitsen naar zelfstandigen en loondienst)

- \% instroom in werk (vanuit bijstand, WW, WIA, ZW, geen inkomen)

- Gemiddelde pensioenleeftijd werknemers (leeftijd op basis van GBA)

\section{Intermediaire effecten (beleid op taakverlichting en taakuitbreiding)}

- (NEA) \% werknemers dat aangeeft...

- ...gemakkelijk een andere baan te kunnen vinden bij huidige werkgever

- ...gemakkelijk een andere baan te kunnen vinden bij een andere werkgever

- ...in de laatste 2 jaar van functie is veranderd

- ...in de laatste 2 jaar een functie uitbreiding heeft gehad

- ...in de laatste 2 jaar een promotie heeft gemaakt

- ...in de laatste 2 jaar van een hogere naar een lagere functie is gegaan

\section{Verhogen inzetbaarheid werknemers}

- $\%$ werknemers dat in de afgelopen vier weken aangeeft een opleiding te volgen die minder dan 6 maanden duurt (EBB)

- Betaald door werkgever

- Betaald door werknemer

\section{Uitkomsten}

\section{Arbeidsparticipatie}

- Bevolking 55-75 jaar (Statline)

- Werkzame beroepsbevolking (EBB) (uitsplitsing naar zelfstandig/loondienst/beide) 
Belangrijkste inkomstenbron (SECMBUS)

- Pensioen/AOW

- $W I A / Z W$

- WW

- Bijstand

- Overig inkomen: inkomen uit sociale voorziening en meewerkend gezinslid

- Geen inkomen

Inkomstenbron (SECMBUS) (iedereen met inkomen uit die bron, dus ook samenloop met andere inkomstenbronnen)

- Pensioen/AOW

- Waarvan samenloop met inkomen uit onderneming/loondienst

- WIA/ZW

- Waarvan samenloop met inkomen uit onderneming/loondienst

- WW

- Waarvan samenloop met inkomen uit onderneming/loondienst

- Bijstand

- Waarvan samenloop met inkomen uit onderneming/loondienst

- Geen inkomen

Hoogte inkomen (INPATAB)

- Gemiddeld persoonlijk bruto-inkomen

Inzetbaarheid (NEA/ZEA 55-65 jaar)

- $\quad \%$ dat gemakkelijk kan voldoen aan fysieke eisen die het werk stelt

- \% dat gemakkelijk kan voldoen aan psychische eisen die het werk stelt

Gezondheid (Gezondheidsenquête) (vanaf 2010)

- Algemene gezondheid (5-puntsschaal) (vanaf 2010)

- Gezonde levensverwachting (Statline)

Alle reeksen zijn waar mogelijk uitgesplitst naar leeftijd, zodat de ontwikkelingen voor 65-jarigen apart in beeld konden worden gebracht. Indien dit niet mogelijk was zijn leeftijdsklassen gehanteerd. Daarnaast zijn waar mogelijk per leeftijdsjaar of per leeftijdsklasse uitsplitsingen gemaakt naar opleidingsniveau (laag, middelbaar, hoog) of inkomensniveau (bruto persoonlijk inkomen).

Voor opleidingsniveau is data uit de betreffende enquête gebruikt waar toepasbaar (EBB, NEA, ZEA, Gecon). Voor de overige tabellen is opleidingsniveau afgeleid vanuit de koppeling met het opleidingsniveaubestand.

Daarbij zijn de volgende inkomensklassen gehanteerd:

1. negatief inkomen of een inkomen van nul

2. hoger dan nul en lager of gelijk aan het minimumloon 
3. hoger dan minimumloon en lager of gelijk aan modaal

4. boven modaal tot twee keer modaal

5. meer dan twee keer modaal 
